\title{
Gas Generation Testing of Neptunium Oxide at Elevated Temperature
}

R. R. Livingston and J. M. Duffey

November 2003

Westinghouse Savannah River Company

Savannah River Site

Aiken, SC 29808

Prepared for the U. S. Department of Energy under contract DE-AC09-96SR18500 
This document was prepared in conjunction with work accomplished under Contract No. DE-AC09-96SR18500 with the U. S. Department of Energy.

\section{DISCLAIMER}

This report was prepared as an account of work sponsored by an agency of the United States Government. Neither the United States Government nor any agency thereof, nor any of their employees, makes any warranty, express or implied, or assumes any legal liability or responsibility for the accuracy, completeness, or usefulness of any information, apparatus, product or process disclosed, or represents that its use would not infringe privately owned rights. Reference herein to any specific commercial product, process or service by trade name, trademark, manufacturer, or otherwise does not necessarily constitute or imply its endorsement, recommendation, or favoring by the United States Government or any agency thereof. The views and opinions of authors expressed herein do not necessarily state or reflect those of the United States Government or any agency thereof.

This report has been reproduced directly from the best available copy.

Available for sale to the public, in paper, from: U.S. Department of Commerce, National Technical Information Service, 5285 Port Royal Road, Springfield, VA 22161, phone: (800) 553-6847, fax: (703) 605-6900

email: orders@ntis.fedworld.gov

online ordering: http://www.ntis.gov/help/index.asp

Available electronically at http://www.osti.gov/bridge

Available for a processing fee to U.S. Department of Energy and its contractors, in paper, from: U.S. Department of Energy, Office of Scientific and Technical Information, P.O. Box 62, Oak Ridge, TN 37831-0062,

phone: (865)576-8401,

fax: (865)576-5728

email: $\underline{\text { reports@ adonis.osti.gov }}$ 


\section{TABLE OF CONTENTS}

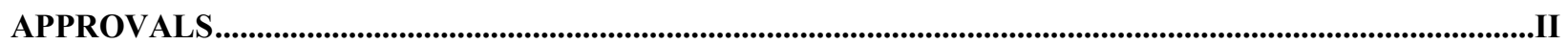

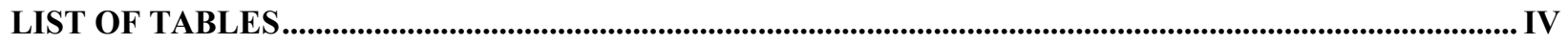

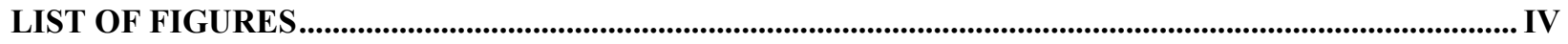

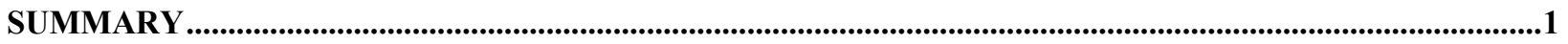

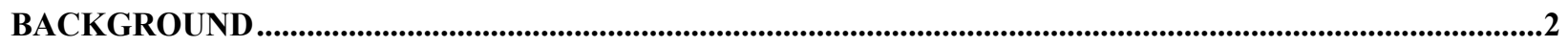

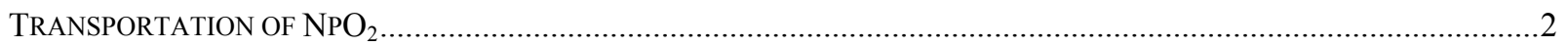

GAS GENERATION BY RADIOACTIVE MATERIALS ..................................................................................

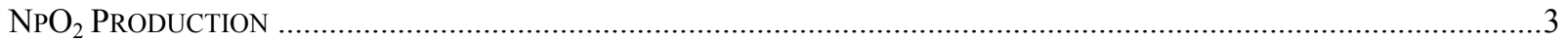

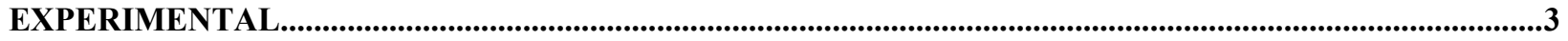

SCOPE

APPARATUS

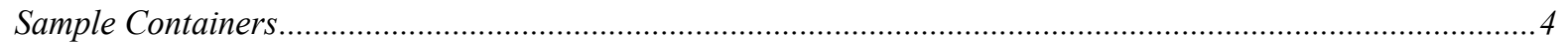

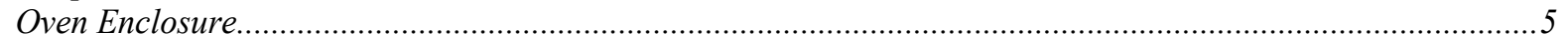

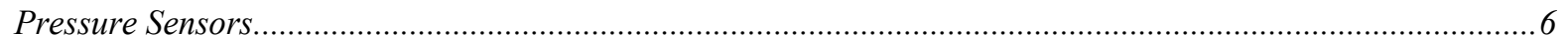

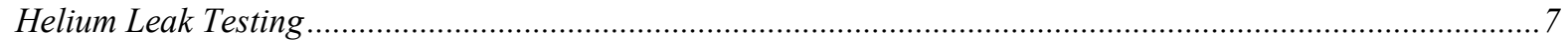

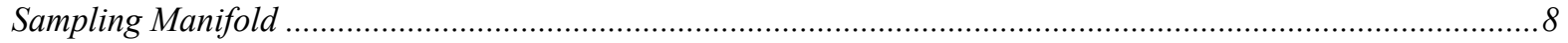

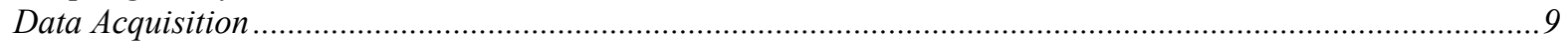

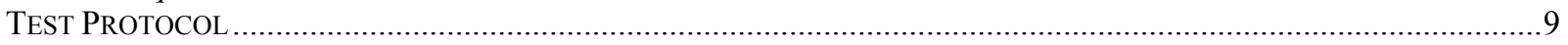

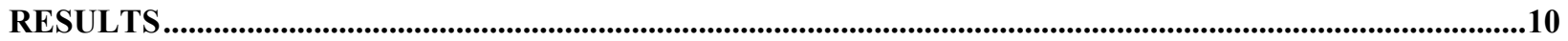

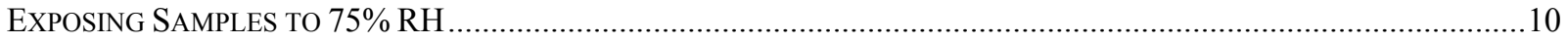

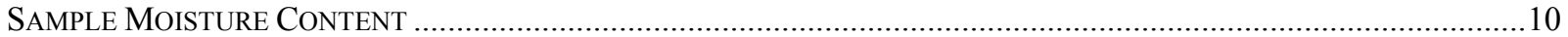

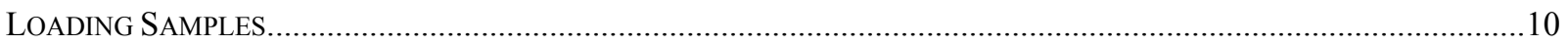

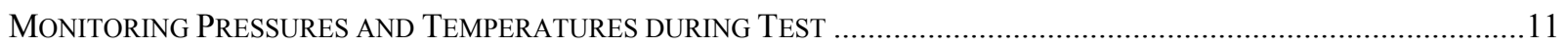

MEASURING CONCENTRATION OF HEADSPACE GASES ........................................................................... 13

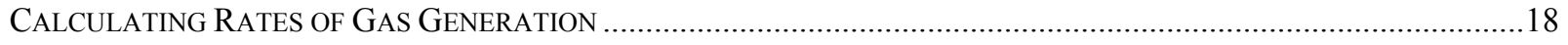

DISCUSSION

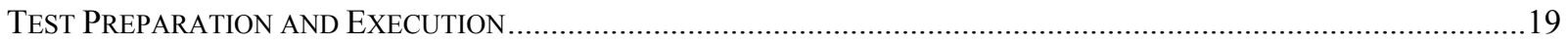

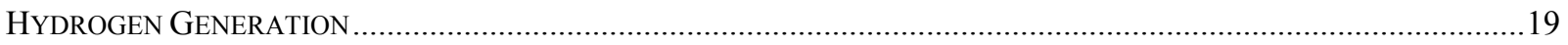

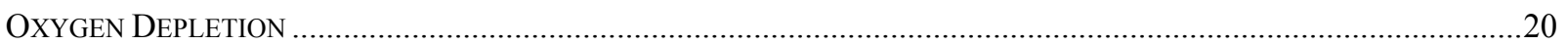

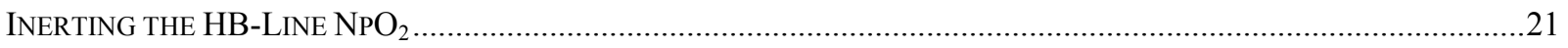

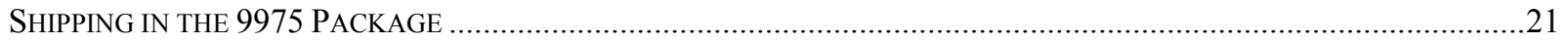

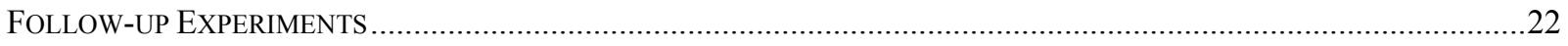

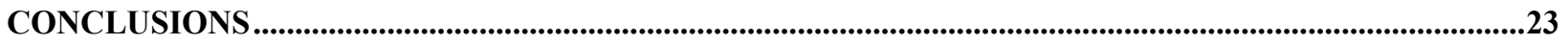

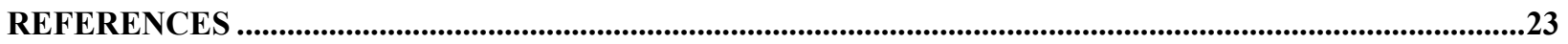


WSRC-TR-2003-00497

Revision 0

\section{List of Tables}

Table 1. $\mathrm{NpO}_{2}$ Samples Used in Elevated Temperature Tests ............................................... 4

Table 2. Composition of Headspace Gas Determined by Micro-GC Analysis. .......................... 17

Table 3. $\mathrm{H}_{2}$ Gas Generation Rates for $\mathrm{NpO}_{2}$ Tests at Elevated Temperature............................ 18

\section{List of Figures}

Figure 1. Test vessel used for $\mathrm{NpO}_{2}$ gas generation experiments........................................ 5

Figure 2. Test vessels, oven enclosure, and temperature controller prior to installation............... 6

Figure 3. Calibration verification for four Digiquartz pressure sensors. ................................. 7

Figure 4. Sample manifold diagram.............................................................................. 8

Figure 5. Temperature corrected pressure measurements for elevated temperature tests. All samples were exposed to $75 \% \mathrm{RH}$ prior to loading in test vessels................................. 12

Figure 6. Temperature profiles for elevated temperature tests. ........................................... 12

Figure 7. Background-subtracted gas chromatograms (low-gain detector signal) of a standard calibration gas containing $0.1 \% \mathrm{H}_{2}$ in air. The low-gain chromatogram is shown because the two largest $\mathrm{N}_{2}$ peaks are off scale in the high-gain chromatogram. ............................. 14

Figure $8 . \mathrm{H}_{2}$ calibration plots obtained using micro-GC apparatus and standard gas mixture containing $0.1 \% \mathrm{H}_{2}$ in air at four different manifold pressures and two different detector gain settings.

Figure 9. $\mathrm{O}_{2}$ calibration plots obtained using micro-GC apparatus and a standard gas mixture containing $0.1 \% \mathrm{H}_{2}$ in air at four different manifold pressures and two different detector gain settings.

Figure $10 . \mathrm{N}_{2}$ calibration plots obtained using micro-GC apparatus and a standard gas mixture containing $0.1 \% \mathrm{H}_{2}$ in air at four different manifold pressures and two different detector gain settings.

Figure 11. Background-subtracted gas chromatograms (high-gain detector signal) of $\mathrm{NpO}_{2}$ headspace gas samples. Two headspace gas aliquots from each $\mathrm{NpO}_{2}$ sample were analyzed, but only one chromatogram from each sample is shown. 
WSRC-TR-2003-00497

Revision 0

\title{
Gas Generation Testing of Neptunium Oxide at Elevated Temperature
}

\author{
R. R. Livingston and J. M. Duffey \\ Westinghouse Savannah River Company \\ Savannah River Site \\ Aiken, SC 29808
}

\section{Summary}

Elevated temperature gas generation tests have been conducted using neptunium dioxide $\left(\mathrm{NpO}_{2}\right)$ produced on a laboratory scale using the HB-Line Phase II flowsheet. These tests are required to support development of the Safety Analysis Report for Packages (SARP) for the 9975 shipping container to include the HB-Line $\mathrm{NpO}_{2}$ product as a new content of the package. These tests were performed to determine what effect elevated temperatures (representative during transport in the 9975) would have on the $\mathrm{NpO}_{2}$ in comparison to $\mathrm{NpO}_{2}$ tested at ambient temperature. The headspace gas compositions following storage at elevated temperatures associated with Normal Conditions of Transport (NCT) have been measured. These test results show an increase in hydrogen $\left(\mathrm{H}_{2}\right)$ generation rate at elevated temperature and significant removal of oxygen $\left(\mathrm{O}_{2}\right)$ from the headspace gas.

The elevated temperature gas generation tests described in this report involved heating small test vessels containing $\mathrm{NpO}_{2}$ and measuring the headspace gas pressure and composition at the end of the test period. Four samples were used in these tests to evaluate the impact of process variables on the gas generation rate. Two samples were calcined to $600{ }^{\circ} \mathrm{C}$ and two were calcined to $650{ }^{\circ} \mathrm{C}$. Each test vessel contained approximately $9.5 \mathrm{~g}$ of $\mathrm{NpO}_{2}$. Following exposure to $75 \%$ relative humidity (RH) for five days, these samples were loaded in air and then heated to between 105 and $115{ }^{\circ} \mathrm{C}$ for about one month. At the conclusion of the test period, the headspace gas of each container was analyzed using a micro-gas chromatograph installed in the glovebox where the experiments were conducted. The pressure, volume, and composition data for the headspace gas samples were used to calculate average $\mathrm{H}_{2}$ generation rates.

These elevated temperature experiments were run in a fashion similar to previous gas generation tests with $\mathrm{NpO}_{2}$ at ambient temperature. ${ }^{1}$ In the ambient temperature tests, the maximum $\mathrm{H}_{2}$ generation rate was determined to be $1.8 \times 10^{-6} \mathrm{~mol} \mathrm{day}^{-1} \mathrm{~kg}^{-1}$ for a $600{ }^{\circ} \mathrm{C}$ $\mathrm{NpO}_{2}$ sample and $1.3 \times 10^{-6} \mathrm{~mol} \mathrm{day}{ }^{-1} \mathrm{~kg}^{-1}$ for a pair of $650{ }^{\circ} \mathrm{C} \mathrm{NpO}_{2}$ samples. In the elevated temperature tests, the calculated rates increased by a maximum factor of 4.0 and 1.6 for the $600{ }^{\circ} \mathrm{C}$ and $650{ }^{\circ} \mathrm{C} \mathrm{NpO}_{2}$, respectively. In both sets of tests, the $\mathrm{O}_{2}$ content of the headspace gas decreased and the rate of $\mathrm{O}_{2}$ decrease was higher at elevated temperature. 
WSRC-TR-2003-00497

Revision 0

\section{Background}

\section{Transportation of $\mathrm{NpO}_{2}$}

The Savannah River Site (SRS) plans to convert neptunium solutions stored in H-Canyon Tank 8.5 to relatively pure $\mathrm{NpO}_{2}$ for transport to $\mathrm{Y}-12$ for storage and eventual use by Oak Ridge National Laboratory (ORNL) to produce plutonium-238. The $\mathrm{NpO}_{2}$ will be transported in the 9975 shipping package. The Savannah River Technology Center (SRTC) is responsible for gas generation testing of the HB-Line $\mathrm{NpO}_{2}$ product to support the required 9975 SARP analysis. Prior work by SRTC on this topic has recently been documented in a series of technical reports describing lab-scale production of $\mathrm{NpO}_{2}$ using the HB-Line flowsheet, characterization of the lab-scale product, and gas generation testing of the lab-scale product at ambient temperature. ${ }^{1,2,3}$

Subsequent review determined additional testing was required to evaluate the $\mathrm{H}_{2}$ generation rate for $\mathrm{NpO}_{2}$ contents at elevated temperature. Based on a thermal model of the 9975 package, the contents under NCT will reach a maximum temperature of $105^{\circ} \mathrm{C}$ $\left(221^{\circ} \mathrm{F}\right) .^{4}$

Including $\mathrm{NpO}_{2}$ as content in the 9975 requires an understanding of the nuclear material behavior under transportation conditions. One of the key requirements for safe transportation of nuclear materials is demonstrating that the transportation package is sufficiently robust to prevent release of the contents under normal and accident conditions. Because radioactive materials are known to generate $\mathrm{H}_{2}$ gas from radiolysis of water or other hydrogenous materials, the contents must have been processed in a manner which prevents over-pressurization of a sealed container.

\section{Gas Generation by Radioactive Materials}

The potential for nuclear materials to generate excessive pressure during transportation and storage has long been recognized as a significant safety hazard. ${ }^{5,6,7}$ Recent efforts to control the moisture content of nuclear materials packaged for extended storage are described in the DOE-STD-3013-2000, "Stabilization, Packaging, and Storage of Plutonium-Bearing Materials," and the DOE-STD-3028-2000, "Criteria for Packaging and Storing Uranium-233-Bearing Materials." These standards require that the nuclear material be processed in a manner that precludes over-pressurization of the storage container. Measured gas generation rates for oxides tested following stabilization and packaging in the prescribed manner demonstrate the effectiveness of these process conditions. ${ }^{10,11} \mathrm{HB}$-Line process conditions were used to produce the $\mathrm{NpO}_{2}$ used in the gas generation tests. That $\mathrm{NpO}_{2}$ has similar characteristics to pure plutonium-bearing oxides packaged per the DOE-STD-3013-2000.,

The observed $\mathrm{H}_{2}$ generation rates for radiolysis of moisture adsorbed on oxide surfaces increase with the moisture content. ${ }^{12,13,14}$ Gas generation rates of radioactive materials are frequently measured by placing a sample in a sealed container and measuring changes in 
pressure and headspace gas composition with time. ${ }^{15,16,17}$ In many cases, the headspace gas content is known when sealing the container and is typically air, helium, or argon, depending on the process atmosphere. The headspace gas is then sampled at a later date to determine changes in the gas composition as a function of time. In sealed systems, $\mathrm{H}_{2}$ and other radiolytic products of water are expected to build up to a steady state concentration at which the back reaction of these products to reform water is equal to the rate of their production from water. ${ }^{18,19,20,21}$ Because the net $\mathrm{H}_{2}$ generation rate decreases as the system approaches steady state, a $\mathrm{H}_{2}$ generation rate measured at low $\mathrm{H}_{2}$ pressures bounds the $\mathrm{H}_{2}$ generation rate over an extended time frame.

\section{$\mathrm{NpO}_{2}$ Production}

During production of $\mathrm{NpO}_{2}$ in HB-Line, the calcination time and temperature will be controlled to produce a low-surface area product which is accurately represented by the $\mathrm{NpO}_{2}$ used in laboratory tests. The $\mathrm{NpO}_{2}$ will be stored in non-vented cans prior to packaging, and the glovebox RH will be monitored to assure the humidity is less than $75 \% \mathrm{RH}$ to limit further moisture adsorption on the oxide surface while exposed to the glovebox atmosphere. Facility start-up testing may need to include baseline specific surface area (SSA) measurements to demonstrate similarity between the $\mathrm{NpO}_{2}$ produced on a laboratory scale and the HB-Line product. Once packaged, the container will be inerted to less than 5 vol $\% \mathrm{O}_{2}$ by evacuating and back-filling with dry argon (Ar).

\section{Experimental}

\section{Scope}

These experiments were designed to measure the gas generation rate of $\mathrm{NpO}_{2}$ samples representing HB-Line Phase II product at the maximum package temperature anticipated for 9975 transport conditions. These experiments were conducted using the same materials described in the report on ambient temperature testing. ${ }^{1}$ The tests included two samples calcined for two hours at $600{ }^{\circ} \mathrm{C}$ and two samples calcined for two hours at $650{ }^{\circ} \mathrm{C}$ as indicated in Table 1 . Both $600{ }^{\circ} \mathrm{C}$ samples were taken from a single oxalate precipitation and calcination batch (600-1A \& 600-1B), which limits the mass of each sample to approximately $9.5 \mathrm{~g}$ of $\mathrm{NpO}_{2}$. The $650{ }^{\circ} \mathrm{C} \mathrm{NpO}_{2}$ samples were from two different oxalate precipitation and calcination batches (650-1A \& 650-2A), and the sample masses used in these tests were also constrained to approximately $9.5 \mathrm{~g}$. Table 1 provides calcination temperature, sample mass and SSA for each sample.

\section{Apparatus}

The apparatus used in these experiments is similar to systems used at Los Alamos National Laboratory (LANL) and ORNL to measure gas generation rates in radioactive materials. ${ }^{10,11}$ Each system has several common components including a stainless steel sample container, pressure transducer, thermocouple, and gas sampling mechanism. The basic function of this apparatus is to contain the sample in a leak-tight environment and 
monitor pressure and temperature during the test period. At the appropriate times, the headspace gases are sampled for analysis of gas composition, and the change in gas composition over the test duration is used to compute the average gas generation rate.

Table 1. $\mathrm{NpO}_{2}$ Samples Used in Elevated Temperature Tests.

\begin{tabular}{|c|c|c|c|}
\hline $\begin{array}{c}\text { Sample } \\
\text { Label }\end{array}$ & $\begin{array}{c}\text { Calcination } \\
\text { Temperature } \\
\left({ }^{\circ} \mathrm{C}\right)\end{array}$ & $\begin{array}{c}\text { Sample Mass } \\
(\mathrm{g})\end{array}$ & $\begin{array}{c}\text { SSA } \\
\left(\mathrm{m}^{2} \mathrm{~g}^{-1}\right)\end{array}$ \\
\hline $600-1 \mathrm{~A}$ & 600 & 9.372 & 5.34 \\
\hline $600-1 \mathrm{~B}$ & 600 & 9.156 & 5.34 \\
\hline $650-1 \mathrm{~A}$ & 650 & 9.405 & 3.68 \\
\hline $650-2 \mathrm{~A}$ & 650 & 9.748 & 3.67 \\
\hline
\end{tabular}

\section{Sample Containers}

The sample containers used in this set of experiments are identical to vessels used in ambient temperature tests, except for the addition of a third Valco valve described below. The test vessels are machined from 304 stainless steel and use a 2.125-inch Conflat flange closure. The inside diameter (ID) of this vessel is sized to accept a variety of stainless steel inserts. The inserts are fabricated from 304 stainless steel with various cavity sizes needed to implement particular test requirements. A single insert size was used in these tests. The cavity of the insert is 0.375 inches in diameter and 2.75 inches deep with a volume of approximately $5 \mathrm{~cm}^{3}$.

All sample container components were cleaned using a fluorocarbon solvent to remove oil and grease to a level below $50 \mathrm{mg}$ of hydrocarbon per square foot. ${ }^{22}$ The components were subsequently heated in a vacuum oven at $200{ }^{\circ} \mathrm{C}$ for about one hour to assure that all solvent had been removed from the vessel components.

The vessel lid contains an Omega type $\mathrm{J}$ thermocouple (TC) with 0.062 -inch diameter 304 stainless steel sheath mounted so that the TC junction is approximately centered in the $\mathrm{NpO}_{2}$ sample. To support gas sampling and analysis, a pair of Valco high-pressure on/off valves is incorporated on the vessel lid and interconnected with a known volume sample loop. This pair of sample valves is connected to the vessel lid by a $10-\mathrm{cm}$ long, 0.010 -inch ID tube with an internal volume of about $5 \mu \mathrm{L}$. This tube is connected to the vessel lid using a Valco fitting with an integral 2- $\mu \mathrm{m}$ sintered metal filter to minimize transfer of the radioactive material during sampling. A second filtered connection is provided to allow connection of a pressure transducer to the vessel lid using a $20-\mathrm{cm}$ long 0.010 -inch ID tube. For the elevated temperature tests, a third valve was added between the vessel lid and the pressure transducer. All Valco fittings used in these vessels and adjoining connections are 300 series stainless steel. Figure 1 is a photograph of a single vessel test apparatus. 


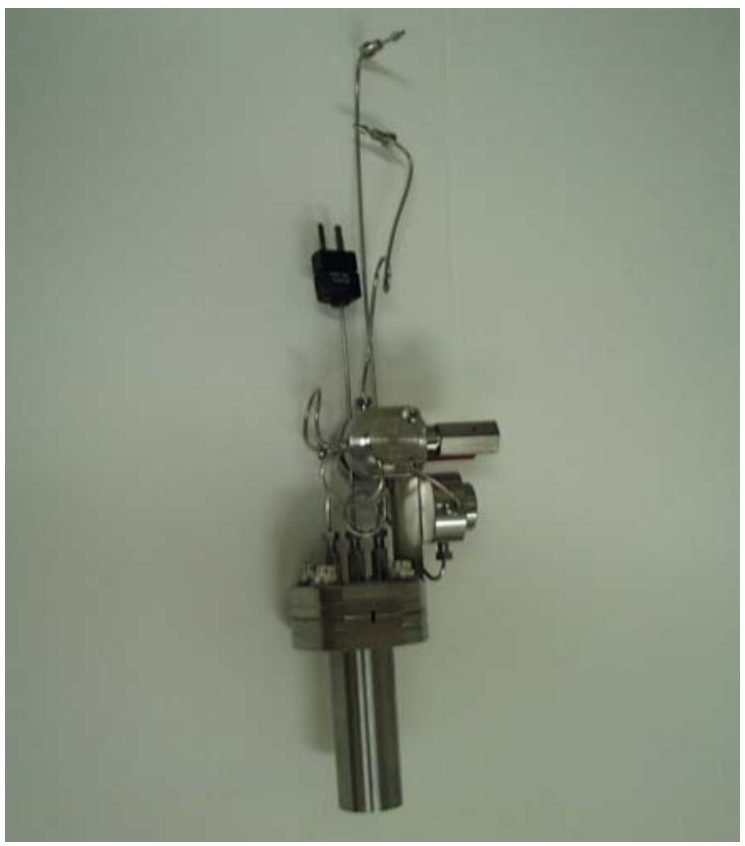

Figure 1. Test vessel used for $\mathrm{NpO}_{2}$ gas generation experiments.

\section{Oven Enclosure}

Based on experience with ambient temperature gas generation tests, an oven enclosure was designed to hold four test vessels for elevated temperature testing. Figure 2 shows the vessels installed in the oven enclosure and temperature controllers prior to use in the radioactive glovebox. This enclosure has the ability to heat samples to about $150{ }^{\circ} \mathrm{C}$ $\left(302^{\circ} \mathrm{F}\right)$ while maintaining the external surface temperature at less than $60^{\circ} \mathrm{C}\left(140{ }^{\circ} \mathrm{F}\right)$. The unit was specifically designed to fit through the existing glovebox opening and includes necessary components to allow redundant temperature controllers to operate outside the glovebox enclosure. This oven enclosure has a built-in rack to hold sample vessels in contact with one of two 100-W heating elements (Chromalox Model SL-B). These heating elements are silicone-rubber insulated and have a heated surface of $2 \times 10$ inches. Slots were cut in the upper surface of the oven enclosure for thermocouple and gas lines to penetrate the box. These gaps are filled with insulation during actual oven operation. The Conflat flange closure of each test vessel is in direct contact with the heating element. This configuration allows the flange closure and exterior vessel surfaces to be maintained at a higher temperature than the center-line temperature of the oxide sample, thus minimizing moisture condensation away from the sample. 


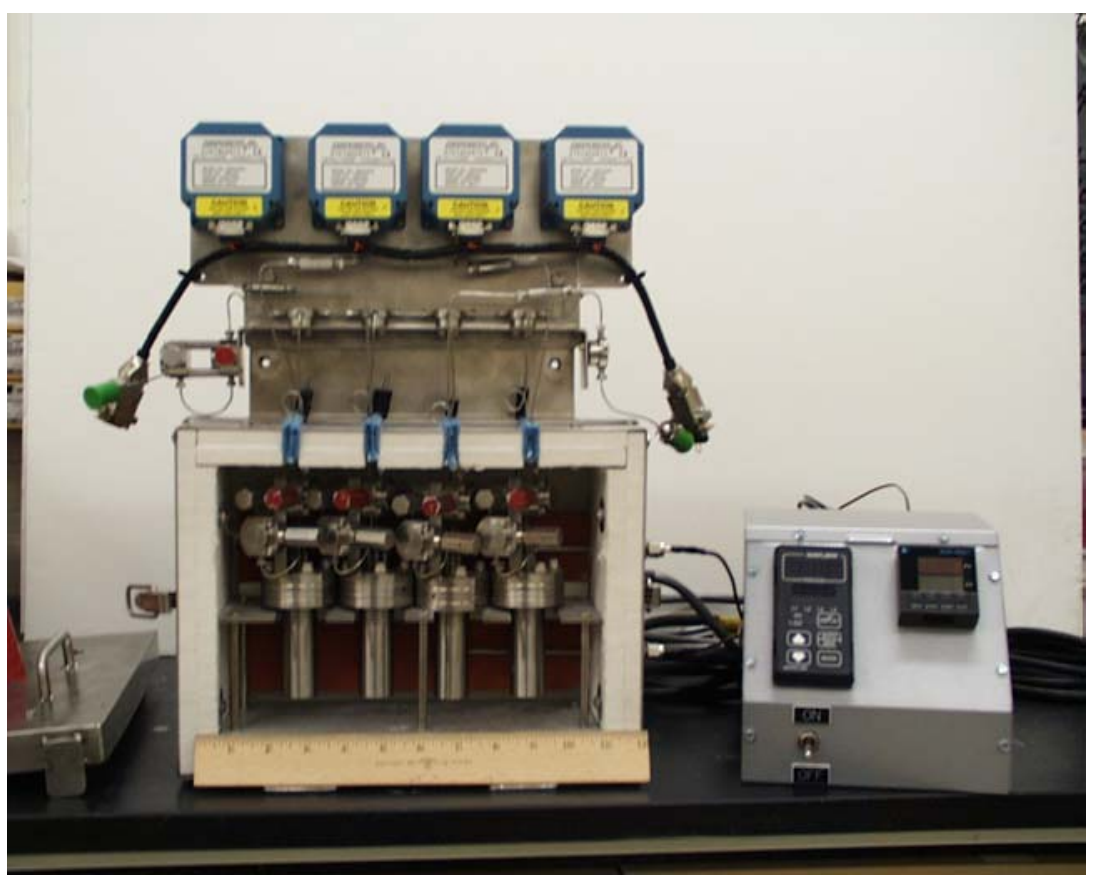

Figure 2. Test vessels, oven enclosure, and temperature controller prior to installation.

\section{Pressure Sensors}

The pressure sensors used in the $\mathrm{NpO}_{2}$ testing are Paroscientific Digiquartz model 6000 . These pressure transducers have about $1 \mathrm{~cm}^{3}$ internal volume and have an accuracy of $\pm 0.01 \%$ full scale, or approximately \pm 0.5 Torr. The model 6000 sensors are temperature compensated over a wide range. Figure 3 shows the calibration verification of the four model 6000 sensors performance against a National Institute of Standards and Technology (NIST) traceable pressure standard. 
WSRC-TR-2003-00497

Revision 0

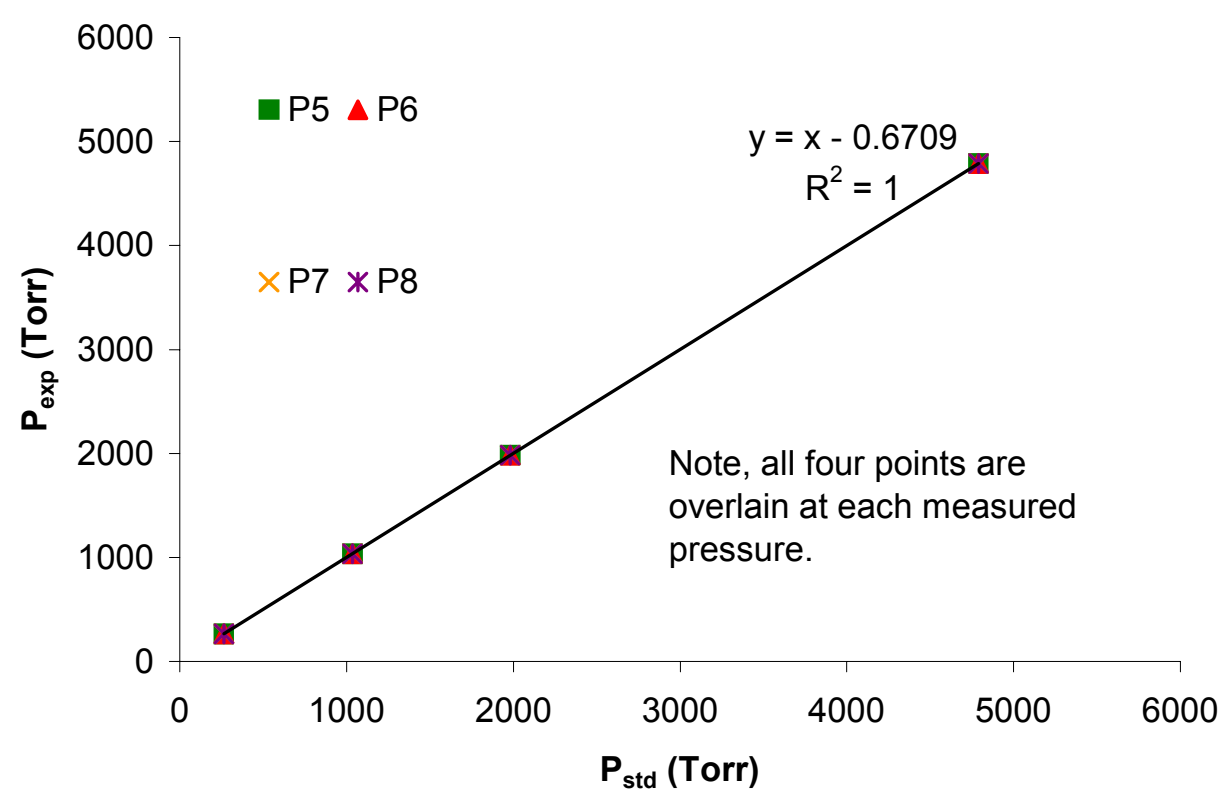

Figure 3. Calibration verification for four Digiquartz pressure sensors.

The temperature range of interest for these elevated temperature tests $\left(>105^{\circ} \mathrm{C}\right)$ is just above the calibrated temperature range for these pressure transducers. Consequently, the sensors were located outside the heated enclosure to maintain the desired performance. To prevent moisture from evaporating in the heated sample vessel and condensing in the pressure transducer, which is maintained at ambient temperature, the pressure transducer is isolated while samples are heated.

\section{Helium Leak Testing}

Prior to installation in the radioactive glovebox, all components of the gas generation test apparatus were helium leak tested. The vessel bottom and lid were assembled using a silver-plated nickel gasket identical to the gaskets used in actual tests with $\mathrm{NpO}_{2}$. This connection can only be helium leak tested during the initial production of vessels, and then must be maintained by careful handling of the vessel components to prevent damage to the sealing surfaces. All vessels were assembled and leak tested using helium pressure in excess of 100 psig where possible. The design of these vessels required that the connection between the pressure transducer and test vessel be tested using a "hood test" instead of the normal "bell jar test." The bell jar test is more sensitive to small leaks; however, either test is an excellent measure of leak rate given the low pressures used in $\mathrm{NpO}_{2}$ gas generation tests.

Helium leak rate measurements demonstrate that the apparatus components are properly assembled and have leak rates less than $1 \times 10^{-9} \mathrm{std} \mathrm{cm}^{3} \mathrm{~s}^{-1}$. Leak rates for components following installation in the glovebox are done using a "rate of rise" method that requires the container to be evacuated to a low pressure. This method measures the rate of 
pressure rise in an evacuated system to calculate the leak rate. This type of measurement is less sensitive than a helium leak test and is only for components that are expected to hold gas samples for a short duration.

\section{Sampling Manifold}

The outlet on each pair of sample valves is connected to a small manifold to support gas sampling at the end of each test. This manifold is comprised of Valco fittings and small bore tubing and provides a connection for the four sample vessels to the gas analysis system installed in the same glovebox. A diagram of major components in the gas analysis system is illustrated in Figure 4.

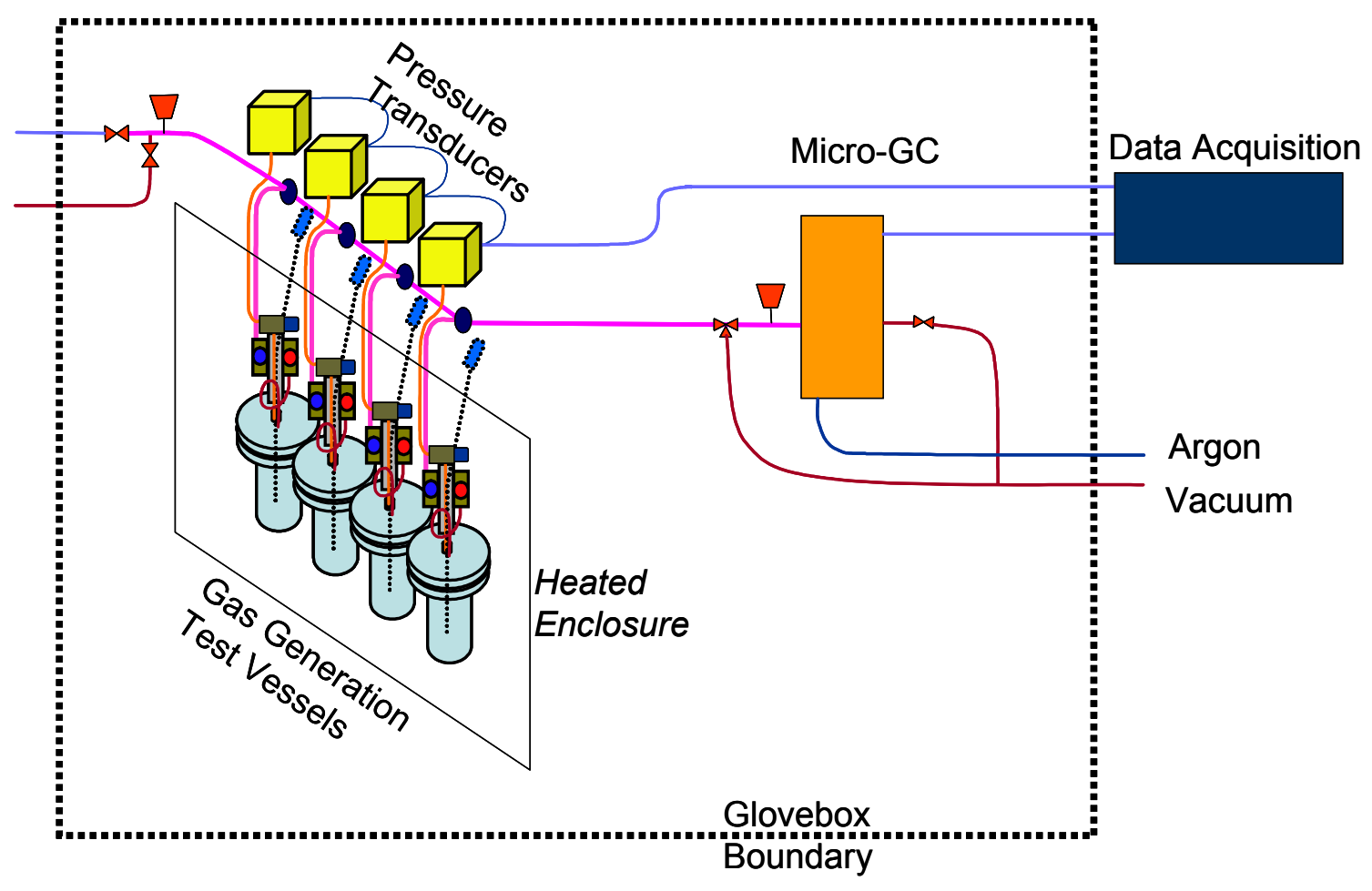

Figure 4. Sample manifold diagram.

The vacuum required for gas sampling and operation of a micro-gas chromatograph (micro-GC) was provided by an Alcatel Drytel Model 1024 molecular drag pump to provide oil free vacuum down to about $1 \times 10^{-6}$ Torr. The micro-GC was calibrated using a NIST traceable gas standard containing $\mathrm{H}_{2}, \mathrm{O}_{2}$, and nitrogen $\left(\mathrm{N}_{2}\right)$ in concentrations similar to those expected in the headspace of test vessels. The chromatograph was calibrated by evacuating the gas manifold and adding standard from a sample loop into the manifold. Once the standard gas was expanded, the gas manifold pressure was measured and used to calculate the partial pressure of each gas component. The manifold was then pressurized with argon to about 1000 Torr immediately prior to initiating the gas analysis. 
Calibration curves were prepared for $\mathrm{H}_{2}, \mathrm{O}_{2}$, and $\mathrm{N}_{2}$ by plotting the integrated peak areas from the standard gas against partial pressure of each component. Each calibration consists of at least four data points including the blank and three pressures of standard. The linear least square fits of these calibration data were then used to calculate partial pressure of each component in the sample gas. Then, the concentration of each gas component was calculated based on the total pressure of sample present in the gas manifold just prior to the analysis.

\section{Data Acquisition}

The temperature and pressure sensors installed in each test vessel were connected to a laboratory computer (Dell model Optiplex 260) using National Instruments Field Point modules and RS485 serial communications. The temperature and pressure measurements for each vessel were presented in graphical form and stored in data files using National Instruments LabView software codes developed by SRTC. This code has been validated by inputting known signals and observing recorded results under the various operating modes. Temperature measurements for the heated enclosure were also recorded. The data storage intervals are adjustable, but are typically set at one data point every 5 to 30 seconds during test set-up and increased to one data point every 300 or 600 seconds during extended test periods. The data are stored in a format compatible with Microsoft Excel, which was used for data reduction and subsequent calculations. Excel spreadsheet calculations were verified using a hand-held calculator.

\section{Test Protocol}

The elevated temperature gas generation experiments followed a similar protocol described for ambient temperature testing:

1. Exposing samples to $75 \% \mathrm{RH}$

2. Loading test vessels with samples

3. Monitoring pressure and temperature during test

4. Measuring concentration of headspace gases

5. Calculating rates of gas generation

Based on prior experience with exposure of the $\mathrm{NpO}_{2}$ samples to $75 \% \mathrm{RH}$, the moisture measurement step used in ambient temperature tests was omitted in the test protocol for elevated temperature testing. Each step of the test protocol is described individually in the following paragraphs. 
WSRC-TR-2003-00497

Revision 0

\section{Results}

\section{Exposing Samples to 75\% RH}

Samples were exposed to $75 \% \mathrm{RH}$ as previously described for ambient temperature gas generation testing. ${ }^{3}$ Details of the moisture uptake efforts are provided in a separate report on characterization of the $\mathrm{NpO}_{2}$ samples. ${ }^{3}$ A saturated $\mathrm{NaCl}$ solution was used to provide the $75 \% \mathrm{RH}$ environment, based on ASTM "Standard Practice for Maintaining Constant Relative Humidity by Means of Aqueous Solutions." 23 The vapor above this salt mixture was circulated through a sealed system using a small pump. The stainless steel inserts containing the specified quantity of $\mathrm{NpO}_{2}$ were exposed to $75 \% \mathrm{RH}$ using a twocontainer apparatus that circulated humidified air from the saturated $\mathrm{NaCl}$ solution around the $\mathrm{NpO}_{2}$ samples. The function of this apparatus was confirmed using a small $\mathrm{RH}$ sensor on the bench top prior to use in the glovebox. This measurement demonstrated that the RH in the chamber reached 75\% RH quickly after sealing. All the samples in this test were exposed to elevated humidity prior to loading in the test vessels.

Both the $600{ }^{\circ} \mathrm{C}$ and $650{ }^{\circ} \mathrm{C} \mathrm{NpO}_{2}$ samples used in these experiments were previously exposed to $75 \% \mathrm{RH}$ prior to ambient temperature testing. ${ }^{1}$ No steps were taken to remove moisture from the samples intentionally prior to their reuse in these experiments. However, previous observations indicate that small amounts of water are lost during sample handling due to the lower (i.e., 40 to $50 \% \mathrm{RH}$ ) humidity typically found in the glovebox used for these experiments. Consequently, the samples were placed back in the humidity chamber for storage. The samples remained in the elevated humidity for about five days before loading. Every effort was made for the rapid transfer of each individual sample to the selected test vessel and seal the test vessel. This process required about five minutes to complete, while the remaining samples were kept in the humidity chamber until loaded.

\section{Samples Moisture Content}

Samples were not analyzed for moisture prior to loading in test vessels. Measurements made previously during ambient temperature testing ${ }^{3}$ are adequate to characterize moisture content. Based on this prior work, moisture content is expected to reach about $0.13 \mathrm{wt} \%$ for $600{ }^{\circ} \mathrm{C}$ oxide and $0.09 \mathrm{wt} \%$ for the $650{ }^{\circ} \mathrm{C}$ oxide when stored at $75 \% \mathrm{RH}$. As shown in the previous testing, ${ }^{1,3}$ the moisture content can be controlled by calcination temperature and $\mathrm{RH}$ limits during processing.

\section{Loading Samples}

The gas generation test vessels were designed to accept stainless steel inserts to allow for simplified loading and unloading of test materials. The inserts were cleaned as described for other test vessel components. Each vessel was inscribed with a sample designation to prevent misidentification during moisture loading. The initial "insert mass" and subsequent changes in the "insert + sample mass" were used to determine the amount of $\mathrm{NpO}_{2}$ used in a given experiment. With cavity volumes of $5 \mathrm{~cm}^{3}$, the inserts easily 
accepted the desired $9.5 \mathrm{~g}$ samples, given the previously measured bulk density of about $1.9 \mathrm{~g} \mathrm{~cm}^{-3}$ and tap density of $2.5 \mathrm{~g} \mathrm{~cm}^{-3}$. The test vessels were approximately 80 to $90 \%$ full. The actual sample masses for all samples are provided in Table 1.

The test vessel gas volumes for this test configuration were previously measured during the ambient temperature test efforts as part of the inerting test sequence. ${ }^{1}$ The measurement results indicate that the volumes of these containers are tightly controlled based on the dimensional specifications used in machining each test vessel. It was also noted as part of the inert gas generation testing of $\mathrm{NpO}_{2}$ at ambient temperature that this process is expected to remove a significant quantity of moisture-even when the evacuation step is of short duration. Therefore, to avoid removing moisture from the sample, the headspace gas volumes of the current tests containers were not measured. Instead, the volumes were estimated based on the previously measured container volumes determined with the same size sample and insert. Addition of the new valve and longer sample line is expected to add, at most, $0.2 \mathrm{~cm}^{3}$ to the test vessel volume. Therefore, with the sample in place the total gas volume was estimated to be $7.50 \pm 0.25 \mathrm{~cm}^{3}$ for each of the sample containers. These experiments were conducted in air and no baseline headspace gas compositions were measured.

\section{Monitoring Pressures and Temperatures during Test}

A Paroscientific Digiquartz pressure transducer was used to monitor the pressure changes in each test vessel. The $0.01 \%$ accuracy of this sensor provides pressure measurements that are within \pm 0.5 Torr of actual pressure. The Digiquartz sensor electronics have little sensitivity to fluctuations in ambient temperature; however, the pressure in a sealed volume shows significant fluctuations in measured pressure unless corrected for changes in gas temperature. The temperature of each test vessel was measured using a type J thermocouple located in the $\mathrm{NpO}_{2}$ sample. The temperature measurements were used to provide temperature-corrected pressure graphs for each sample vessel. Data files are stored on the laboratory computer by the LabView software.

This set of experiments was run for 30 days. The initial headspace gas in this set of experiments was air. The temperature-corrected pressure graph for these samples is provided in Figure 5. Samples were started at ambient pressure with the pressure transducer isolation valve open. The isolation valve was closed prior to heating to avoid condensation of moisture on the cooler surfaces. Once the samples were cooled to ambient temperature over about four hours, the isolation valve was opened and pressure was recorded. The isolation valve was sealed and the samples returned to elevated temperature. During this pressure measurement cycle, the pressure transducer signal remained nearly constant as pressure changed in the sealed vessel. Upon repeating the cycle, the new pressure data point was recorded. This cycle was typically repeated twice each week during the duration of the experiment. This process is shown in the graph of vessel temperature versus time in Figure 6. 
WSRC-TR-2003-00497

Revision 0

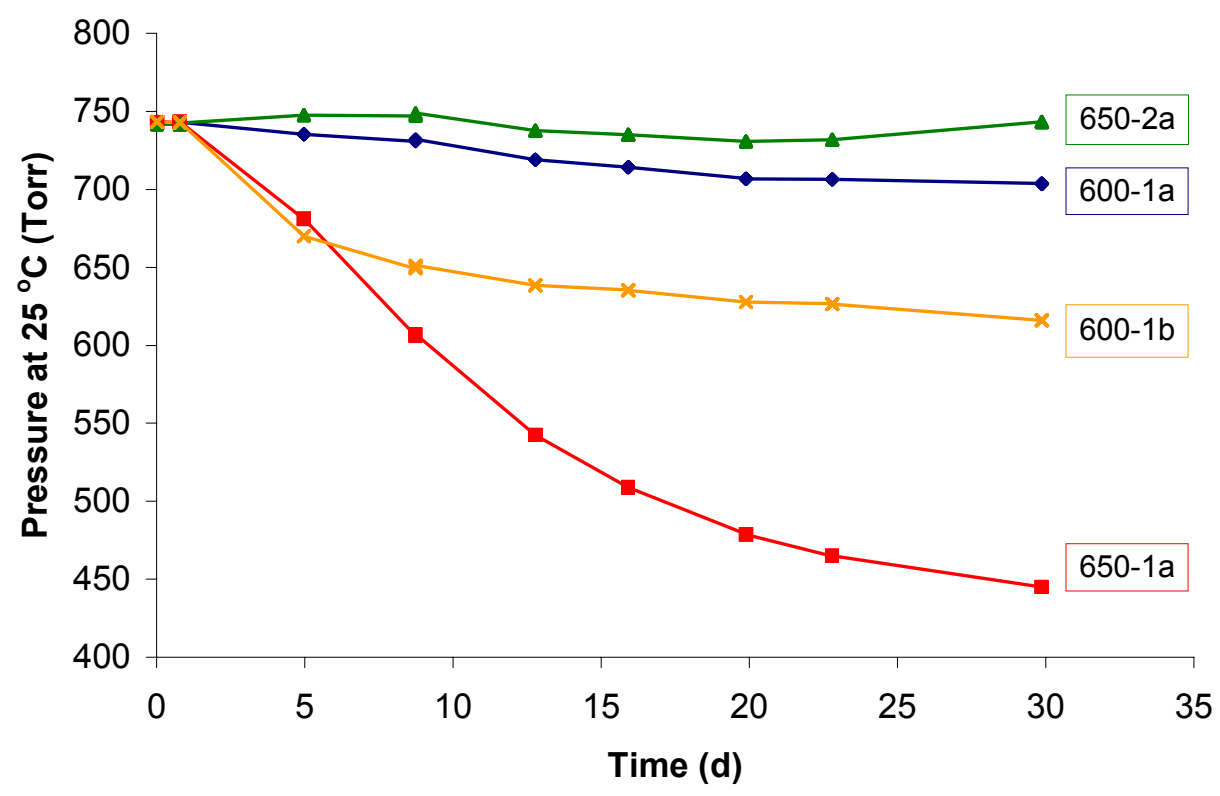

Figure 5. Temperature corrected pressure measurements for elevated temperature tests. All samples were exposed to $75 \% \mathrm{RH}$ prior to loading in test vessels.

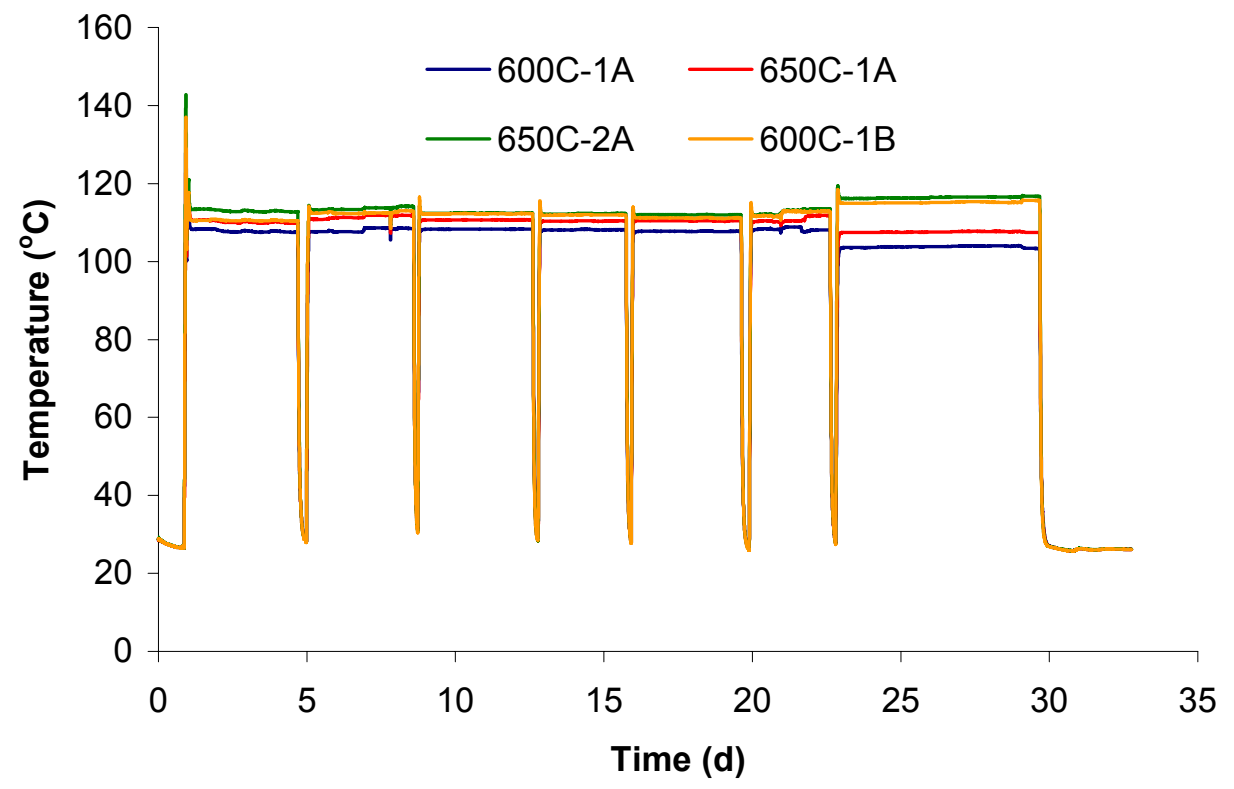

Figure 6. Temperature profiles for elevated temperature tests. 
Following the last temperature cycle, the pressure began to rise in the test vessel containing sample 650C-1A. This pressure rise indicates a leak and corroborates the expectation of a leak, based on the large drop in pressure during the initial 30 days of testing. Following completion of the gas generation tests, the sample 650C-2A test vessel was opened to sample the $\mathrm{NpO}_{2}$ for analysis of metals composition. The silver-plated nickel gasket had a darker color (brown/black) on the inner surface than observed previously in ambient temperature tests, ${ }^{1}$ but there were no visible problems identified with the sealing surfaces. After resealing the empty test vessel, the unit was evacuated and valves closed to provide a leak check using the rate of rise technique. This test was conducted over a 24-hour period and indicated a leak rate of about $2 \times 10^{-8} \mathrm{~cm}^{3} \mathrm{sec}^{-1}$, compared to a leak rate of $2 \times 10^{-6} \mathrm{std} \mathrm{cm}^{3} \mathrm{sec}^{-1}$ observed at the end of the 30-day test. This behavior is additional confirmation that the vessel was leaking and indicates that the leak was largely eliminated when the vessel was resealed.

\section{Measuring Concentration of Headspace Gases}

Headspace gas samples were collected in the same manner from each test vessel by using the sample loop built into each test vessel. The limited duration of these tests and anticipated reduction in the $\mathrm{H}_{2}$ gas generation rate at elevated temperature prompted installation of the micro-GC in the radioactive glovebox. Measurement sensitivity is increased by a factor of about five by eliminating the large reduction in sample pressure associated with expansion of the gas into a sample container prior to analysis. ${ }^{1}$ The micro-GC used for this analysis is the same system previously used in ambient temperature gas generation testing. With the increased headspace gas pressure, the sample size required for each analysis becomes a fraction of the available gas in each test vessel. Consequently, the limitations associated with earlier SRTC gas generation tests $^{1,14,15,16}$ were overcome, and gas analysis could be conducted during the course of an experiment. The micro-GC can provide analysis for $\mathrm{H}_{2}$ at a concentration of $0.01 \%$ using as little as $0.02 \mathrm{std} \mathrm{cm}^{3}$ of gas, or about $0.3 \%$ of the total sample gas volume. Further documentation of the micro-GC functions and analytical capability are provided in another SRTC technical report specifically addressing the development of a micro-GC for use with gas generation testing applications. ${ }^{24}$

The software used for operating the micro-GC was custom developed for this application. The functions of this custom LabView code were validated by comparison with measurement results obtained using the commercial software product for prior ambient temperature gas generation testing. The custom software addresses problems associated with saving sample chromatograms for presentation and review following the data collection. Other limitations addressed in the custom software include difficulties associated with calibration, baseline subtraction, and documentation of sample or calibration data. With the current software, GC results are easily exported to support calculation of headspace gas compositions using an Excel spreadsheet.

The calibration gas $\left(0.1 \% \mathrm{H}_{2}\right.$ in air) used for the micro-GC was connected to the gas manifold in a similar fashion as the test vessels. The container filled with calibration gas was also connected to an external manifold which supported evacuation and filling with a 
traceable standard. Calibration of the micro-GC was conducted just prior to the sample analysis. Quality control checks of the system performance were conducted periodically during and after the sample analysis with standard gas at various pressures. Numerous blanks were also analyzed to demonstrate no sample carryover or interferences in the analysis of $\mathrm{H}_{2}, \mathrm{O}_{2}$, or $\mathrm{N}_{2}$.

Background-subtracted chromatograms for the standard gas mixture at four different manifold pressures are shown in Figure 7. The micro-GC detector (thermal conductivity detector) signal intensity (both at high and low gain) was recorded once every 10 milliseconds. The relative peak areas were obtained by summing the backgroundsubtracted signal intensities over the following retention times: $\mathrm{H}_{2}(8.30$ to $9.50 \mathrm{~s}) ; \mathrm{O}_{2}$ (10.10 to $11.70 \mathrm{~s}$ ); and $\mathrm{N}_{2}$ (11.71 to $16.00 \mathrm{~s}$ ).

Calibration curves were generated by plotting relative peak areas for both the high and low gain signals versus partial pressure for each gas. Calibration plots for $\mathrm{H}_{2}, \mathrm{O}_{2}$, and $\mathrm{N}_{2}$ are shown in Figures 8, 9, and 10, respectively. As seen from the slopes of the calibration curves for each gas, the detector response is about 10 times greater for $\mathrm{H}_{2}$ than for either $\mathrm{O}_{2}$ or $\mathrm{N}_{2}$. This greater sensitivity for $\mathrm{H}_{2}$ is due to the larger difference in the thermal conductivities of $\mathrm{H}_{2}$ and argon (Ar) carrier gas as compared to the differences between $\mathrm{O}_{2}$ and $\mathrm{Ar}$ or $\mathrm{N}_{2}$ and Ar.

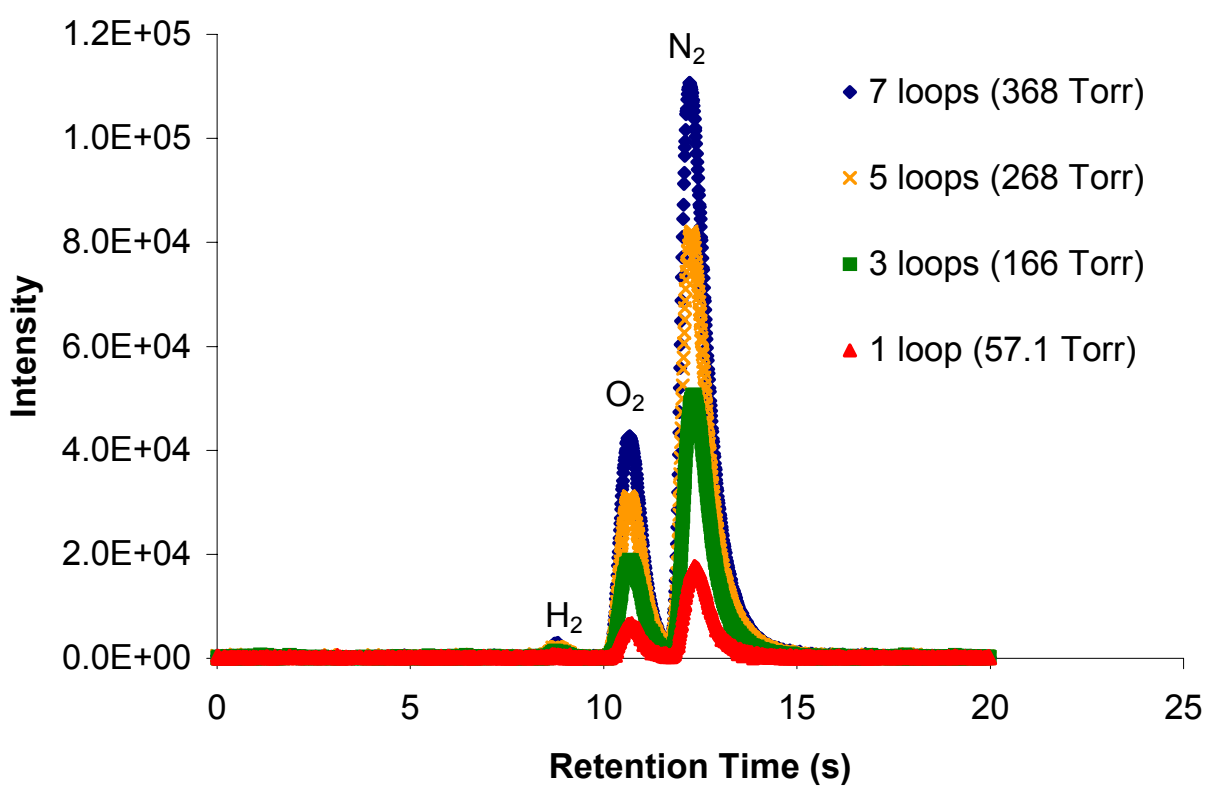

Figure 7. Background-subtracted gas chromatograms (low-gain detector signal) of a standard calibration gas containing $0.1 \% \mathrm{H}_{2}$ in air. The low-gain chromatogram is shown because the two largest $\mathrm{N}_{2}$ peaks are off scale in the high-gain chromatogram. 
WSRC-TR-2003-00497

Revision 0

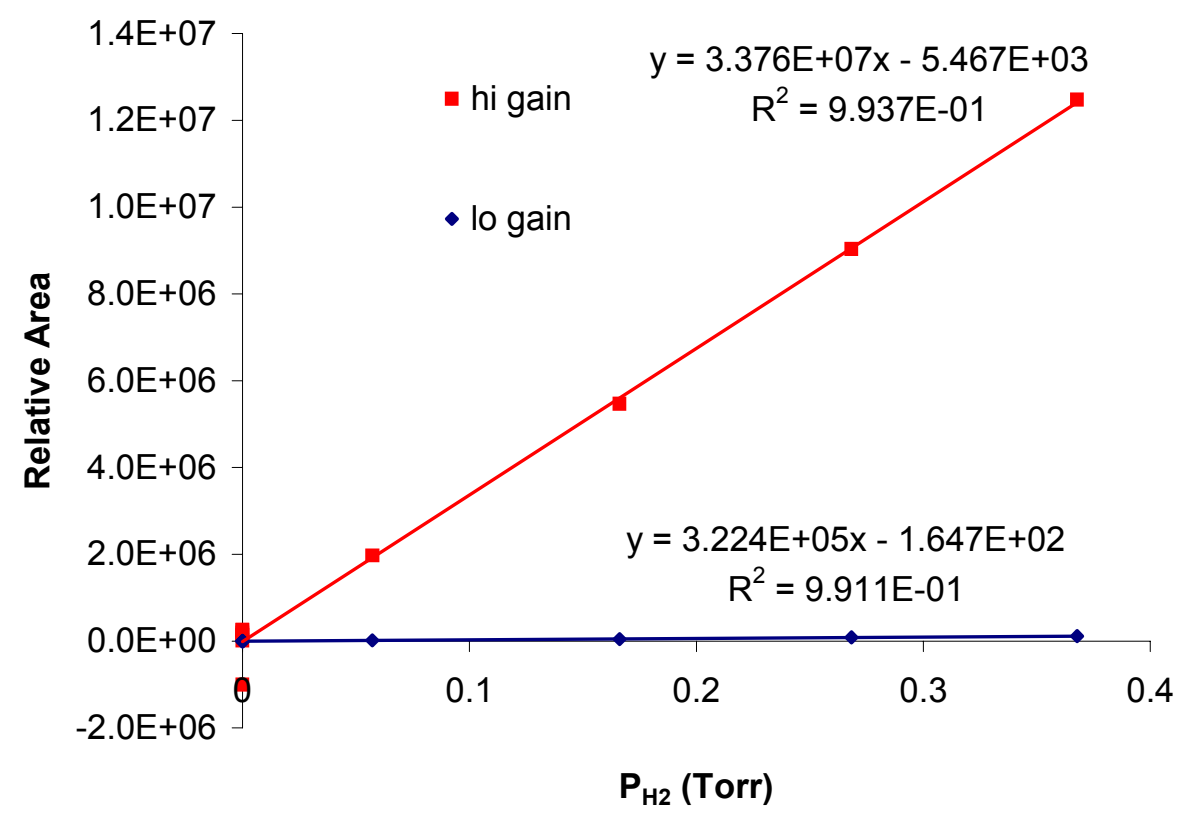

Figure 8. $\mathrm{H}_{2}$ calibration plots obtained using micro-GC apparatus and standard gas mixture containing $0.1 \% \mathrm{H}_{2}$ in air at four different manifold pressures and two different detector gain settings.

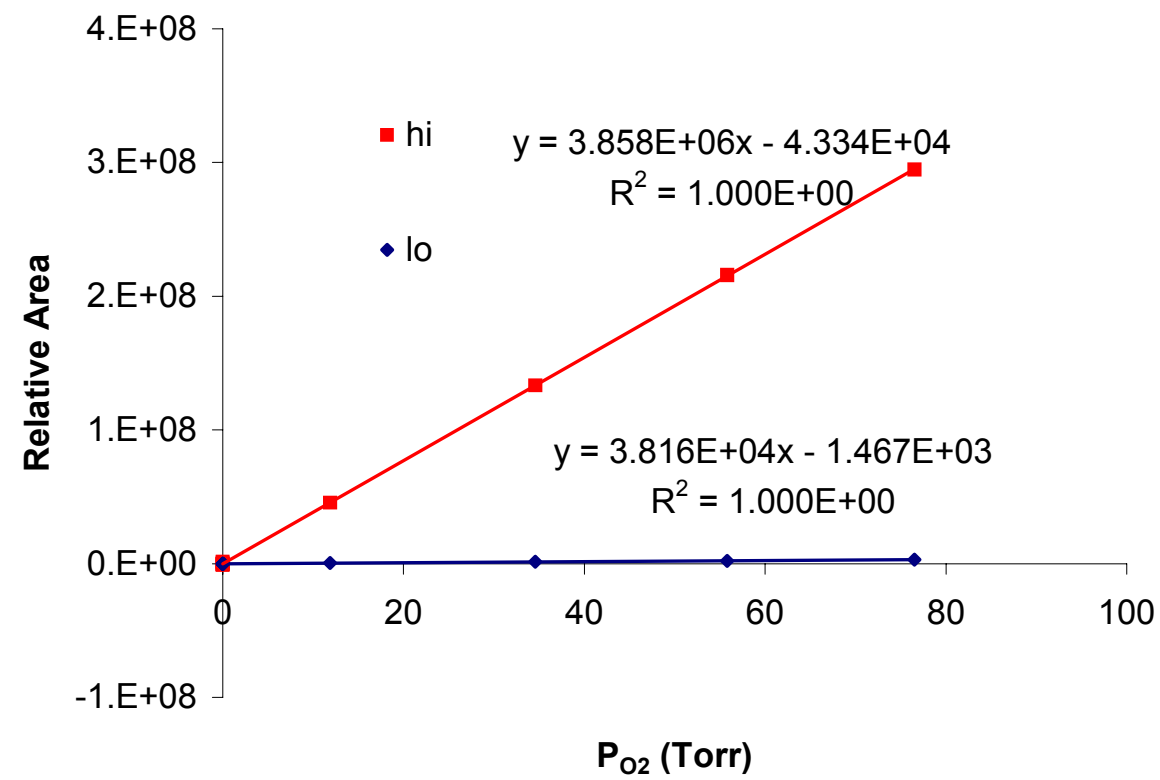

Figure 9. $\mathrm{O}_{2}$ calibration plots obtained using micro-GC apparatus and a standard gas mixture containing $0.1 \% \mathrm{H}_{2}$ in air at four different manifold pressures and two different detector gain settings. 
WSRC-TR-2003-00497

Revision 0

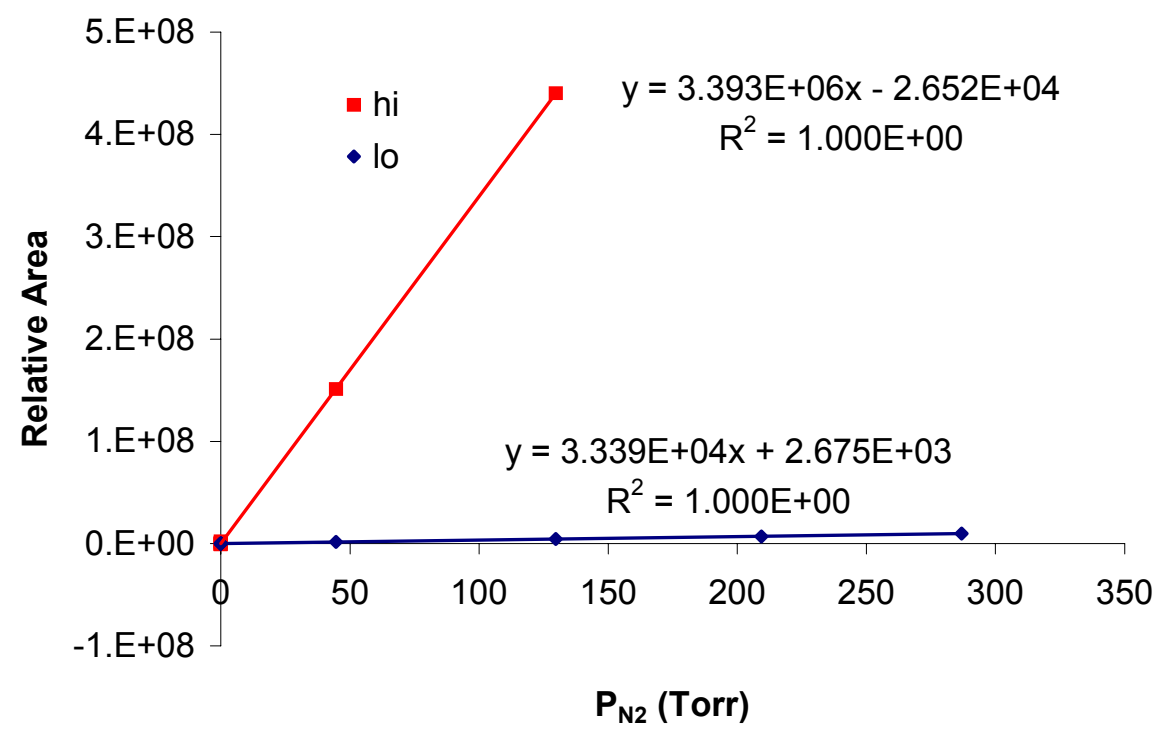

Figure 10. $\mathrm{N}_{2}$ calibration plots obtained using micro-GC apparatus and a standard gas mixture containing $0.1 \% \mathrm{H}_{2}$ in air at four different manifold pressures and two different detector gain settings.

Prior to sampling the headspace gas for analysis, the $30-\mu \mathrm{L}$ sample loop was evacuated to less than 1.0 Torr along with the entire gas manifold. The number of sample loops of gas added to the gas manifold was varied, depending on headspace gas composition. Two headspace gas aliquots from each $\mathrm{NpO}_{2}$ sample vessel were analyzed. Figure 11 shows one background-subtracted chromatogram for each of the four $\mathrm{NpO}_{2}$ samples. Only $\mathrm{H}_{2}$, $\mathrm{O}_{2}$, and $\mathrm{N}_{2}$ peaks were observed in the sample gas chromatograms.

Relative peak areas were determined in the same manner, and using the same peak retention times, as described previously for the calibration gas peak areas. The volume percentages of each component in the headspace gas samples were calculated as follows:

$$
\text { Vol } \%=\frac{A-b}{m \cdot P_{t o t}} \times 100 \% \text {, }
$$

where $A$ is the relative peak area, $b$ and $m$ are the intercept and slope of the appropriate calibration curve, respectively, and $P_{t o t}$ is the total headspace gas sample pressure in the micro-GC manifold prior to addition of Ar and injection of sample into the micro-GC. Volume percentages were calculated from both the low-gain and high-gain peak areas, then averaged to obtain a final gas concentration. Results of the micro-GC analysis for the elevated temperature $\mathrm{NpO}_{2}$ headspace gas samples are provided in Table 2 . 


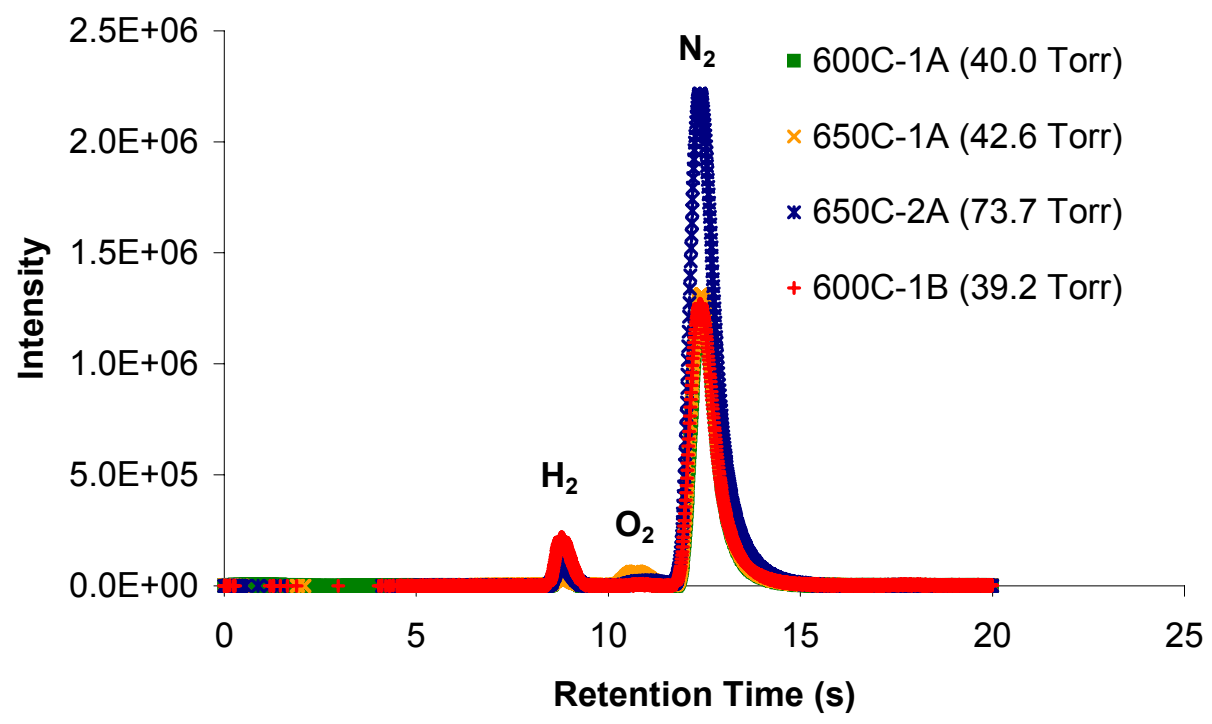

Figure 11. Background-subtracted gas chromatograms (high-gain detector signal) of $\mathrm{NpO}_{2}$ headspace gas samples. Two headspace gas aliquots from each $\mathrm{NpO}_{2}$ sample were analyzed, but only one chromatogram from each sample is shown.

Table 2. Composition of Headspace Gas Determined by Micro-GC Analysis.

\begin{tabular}{|c|c|c|c|c|c|c|c|c|}
\hline \multirow[b]{2}{*}{ Sample ID } & \multirow{2}{*}{$\begin{array}{c}\text { Run } \\
\#\end{array}$} & \multirow{2}{*}{$\begin{array}{l}\mathrm{P}_{\text {tot }} \\
\text { (Torr) }\end{array}$} & \multicolumn{2}{|c|}{$\mathrm{H} 2 \%$} & \multicolumn{2}{|c|}{$\mathrm{O} 2 \%$} & \multicolumn{2}{|c|}{$\mathrm{N} 2 \%$} \\
\hline & & & Lo gain & Hi gain & Lo gain & Hi gain & Lo gain & Hi gain \\
\hline \multirow[t]{3}{*}{$600 \mathrm{C}-1 \mathrm{~A}$} & 1 & 20.8 & 0.20 & 0.24 & 2.52 & 2.57 & 82.04 & 81.25 \\
\hline & 2 & 40.0 & 0.20 & 0.23 & 1.67 & 1.46 & 78.46 & 78.80 \\
\hline & Avg $^{1}$ & & \multicolumn{2}{|c|}{$0.22 \pm 0.02$} & \multicolumn{2}{|c|}{$2.05 \pm 0.57$} & \multicolumn{2}{|c|}{$80.14 \pm 1.78$} \\
\hline \multirow[t]{3}{*}{$600 \mathrm{C}-1 \mathrm{~B}$} & 1 & 39.2 & 0.79 & 0.77 & 0.18 & 0.26 & 81.92 & 81.31 \\
\hline & 2 & 39.0 & 0.81 & 0.77 & 0.20 & 0.15 & 81.51 & 81.66 \\
\hline & avg & & \multicolumn{2}{|c|}{$0.79 \pm 0.02$} & \multicolumn{2}{|c|}{$0.20 \pm 0.05$} & \multicolumn{2}{|c|}{$81.60 \pm 0.26$} \\
\hline \multirow[t]{3}{*}{$650 \mathrm{C}-1 \mathrm{~A}$} & 1 & 317.5 & 0.13 & 0.12 & 1.85 & 1.85 & 77.53 & $\mathrm{NA}^{2}$ \\
\hline & 2 & 42.6 & 0.13 & 0.15 & 2.61 & 2.85 & 77.23 & 77.11 \\
\hline & avg & & \multicolumn{2}{|c|}{$0.13 \pm 0.01$} & \multicolumn{2}{|c|}{$2.29 \pm 0.52$} & \multicolumn{2}{|c|}{$77.29 \pm 0.22$} \\
\hline \multirow[t]{3}{*}{$650 \mathrm{C}-2 \mathrm{~A}$} & 1 & 73.7 & 0.19 & 0.20 & 0.92 & 0.75 & 74.68 & 74.79 \\
\hline & 2 & 72.6 & 0.18 & 0.19 & -0.01 & 0.09 & 75.30 & 75.19 \\
\hline & avg & & \multicolumn{2}{|c|}{$0.19 \pm 0.00$} & \multicolumn{2}{|c|}{$0.44 \pm 0.46$} & \multicolumn{2}{|c|}{$74.99 \pm 0.30$} \\
\hline
\end{tabular}

${ }_{1}^{1}$ Average of four individual results \pm 1 standard deviation.

${ }^{2}$ The $\mathrm{N}_{2}$ peak was off-scale and could not be integrated accurately. 


\section{Calculating Rates of Gas Generation}

Hydrogen gas generation rates were calculated from the experimental data as follows:

$$
\text { rate }=\frac{n_{\mathrm{H}_{2}}}{t \cdot m}
$$

where:

$$
\begin{aligned}
\text { rate } & =\text { moles of } \mathrm{H}_{2} \text { generated per day per kilogram of } \mathrm{NpO}_{2} \\
n_{H 2} & =\text { moles of } \mathrm{H}_{2} \text { produced, } \\
t & =\text { test duration in days, } \\
m & =\text { mass of } \mathrm{NpO}_{2} \text { in kilograms, }
\end{aligned}
$$

The number of moles of $\mathrm{H}_{2}$ produced $\left(n_{H 2}\right)$ was calculated as follows:

where:

$$
n_{H_{2}}=\frac{c_{H_{2}} \cdot p \cdot V}{R \cdot T}
$$

$c_{H 2}=$ volume fraction of $\mathrm{H}_{2}$ in container at end of test,

$p=$ final container pressure in atmospheres,

$V=$ container volume in liters,

$R=$ the ideal gas constant, $0.08206 \mathrm{~L} \cdot \mathrm{atm} / \mathrm{mol} \cdot \mathrm{K}$,

$T=$ absolute temperature in $\operatorname{Kelvins}(\mathrm{K})$.

The calculated gas generation rates are provided in Table 3 along with mass, pressure, volume, and duration for each experiment.

Table 3. $\mathrm{H}_{2}$ Gas Generation Rates for $\mathrm{NpO}_{2}$ Tests at Elevated Temperature.

\begin{tabular}{|l|c|c|c|c|c|}
\hline $\begin{array}{l}\text { Sample } \\
\text { ID }\end{array}$ & $\begin{array}{c}\text { Mass } \\
(\mathrm{g})^{\mathrm{a}}\end{array}$ & $\begin{array}{c}\text { Pressure } \\
(\mathrm{atm})^{\mathrm{b}}\end{array}$ & $\begin{array}{c}\text { Volume } \\
(\mathrm{L})\end{array}$ & $\begin{array}{c}\text { Duration } \\
(\text { days })^{\mathrm{c}}\end{array}$ & $\begin{array}{c}\text { Rate } \\
\left(\mathrm{mol} \mathrm{day}^{-1} \mathrm{~kg}^{-1}\right)\end{array}$ \\
\hline 600C-1A & 9.342 & 0.917 & 0.00750 & 28.8 & $2.30 \times 10^{-6}$ \\
\hline 600C-1B & 9.124 & 0.805 & 0.00750 & 28.8 & $7.42 \times 10^{-6}$ \\
\hline 650C-1 & 9.385 & 0.611 & 0.00750 & 28.8 & $0.90 \times 10^{-6}$ \\
\hline 650C-2 & 9.727 & 0.974 & 0.00750 & 28.8 & $2.02 \times 10^{-6}$ \\
\hline
\end{tabular}

a A dry sample mass is calculated by subtracting the loss on ignition result from the measured sample mass. ${ }^{1,3}$

${ }^{\mathrm{b}}$ Pressure measurements are corrected to $25^{\circ} \mathrm{C}$ or $298 \mathrm{~K}$.

${ }^{\mathrm{c}}$ Duration is time at elevated temperature.

The $\mathrm{H}_{2}$ generation rates have an estimated uncertainty of $\pm 15 \%$ relative standard deviation with the greatest uncertainty contributed by the uncertainties in the $\mathrm{H}_{2}$ concentration and in the container gas volume. The variation in $\mathrm{H}_{2}$ generation rates 
observed for these samples is greater than expected based on measurement uncertainty for these analyses.

\section{Discussion}

\section{Test Preparation and Execution}

The empirical determination of $\mathrm{H}_{2}$ generation rates for a nuclear material is not a simple task, as indicated by the foregoing description of SRTC efforts. These tests required the laboratory scale production of $\mathrm{NpO}_{2}$ which represents the HB-Line Phase II product and extensive characterization of the $\mathrm{NpO}_{2}$ to support interpretation of gas generation test results. Test equipment was specifically designed to support analysis of gas generation from small samples of $\mathrm{NpO}_{2}$ with limited test duration. The elevated temperature value of $105{ }^{\circ} \mathrm{C}$ targeted in these tests is based on thermal modeling ${ }^{4}$ of maximum temperature for shipping the $\mathrm{NpO}_{2}$ in a 9975 package.

Prior efforts to measure gas generation rates for $\mathrm{PuO}_{2}$ at elevated temperature have shown a decrease in the $\mathrm{H}_{2}$ generation rate and rapid removal of $\mathrm{O}_{2}$ from air. ${ }^{25,26}$ The decrease in $\mathrm{H}_{2}$ generation rate could be attributed to evaporation of water from the samples and condensation on cooler surfaces away from the radioactive materials. To overcome this limitation in previous test apparatus designs, the small oven constructed for heating these samples was designed to maintain the test vessel surfaces at a slightly higher temperature than the $\mathrm{NpO}_{2}$ samples. The pressure transducers used in these tests were located outside the oven enclosure to minimize problems associated with transducer performance at elevated temperature. While heating, the pressure transducers were isolated from the sample containers with a miniature valve located inside the heated enclosure. Samples were cooled periodically to ambient temperature prior to opening the miniature valve to make pressure measurements.

\section{Hydrogen Generation}

The $\mathrm{H}_{2}$ generation rates measured at elevated temperature were as much as four times higher than the $\mathrm{H}_{2}$ generation rate measured for the same sample at ambient temperature. Temperature is expected to have little or no effect on radiolysis rates ${ }^{27}$ because the reactions are dependent on the absorbed radiation dose, which is generally not impacted by changes in temperature. Consequently, the gas generation rate associated with radiolysis of moisture is not expected to vary as a function of temperature. However, most chemical reactions are temperature dependent and are characterized by Arrhenius behavior. ${ }^{28}$ For a typical chemical reaction, the reaction rate roughly doubles for every 10 ${ }^{\circ} \mathrm{C}$ rise in temperature.

The observed increase in $\mathrm{H}_{2}$ generation rate for these samples suggests that some portion of the observed $\mathrm{H}_{2}$ generation (and $\mathrm{O}_{2}$ depletion) may result from chemical reactions. This observation is corroborated by recent (November 2003) gas generation tests at 
ambient temperature that indicate measurable $\mathrm{H}_{2}$ generation rates for controls containing cerium dioxide $\left(\mathrm{CeO}_{2}\right)$.

Metal corrosion reactions may generate $\mathrm{H}_{2}$, as well as consume $\mathrm{O}_{2}$. The reaction mechanisms can be complicated and difficult to interpret. ${ }^{29}$ These reactions may be stimulated by the formation of radicals associated with radioactive systems, but should follow Arrhenius behavior as described for chemical reactions. During TGA-MS analysis of the laboratory-scale $\mathrm{NpO}_{2}$ product characterization, sulfur dioxide was observed in the off-gas during heating of the sample. ${ }^{3}$ The initial form of sulfur in the sample has not been determined at this time, but ferrous sulfamate was used in the $\mathrm{NpO}_{2}$ production process and the sulfamate ions are expected to decompose to sulfate ions. Sulfur is known to contribute to the corrosion of both silver and stainless steel. ${ }^{29}$

The silver-plated gaskets used in these experiments were expected to remain unaffected by the elevated temperature test conditions. However when sample 650C-1A was opened following gas analysis, the inner surface of this gasket was darker in color than gaskets removed from similar samples tested at ambient temperature, which may indicate the formation of silver sulfide or silver oxide. The stainless steel test vessels and inserts used in all gas generation tests were machined from 304 stainless steel, and the test vessel used for sample $650 \mathrm{C}-1 \mathrm{~A}$ appeared unaffected by the elevated temperature condition. In addition, the 304 stainless steel thermocouple sheath which is placed directly into the $\mathrm{NpO}_{2}$ powder showed no visible evidence of deterioration.

\section{Oxygen Depletion}

The gas analysis for these elevated temperature samples packaged in air demonstrated that $\mathrm{O}_{2}$ is being removed from the headspace of the samples. Mechanisms for $\mathrm{O}_{2}$ depletion may include reaction with $\mathrm{NpO}_{2}$ to form a hyperstoichiometric $\mathrm{NpO}_{2+\mathrm{x}}$, oxidation of metallic surfaces, oxidation of residual carbon to form carbon oxides (CO or $\mathrm{CO}_{2}$ ), or reaction with $\mathrm{N}_{2}$ by radiolysis of moist air. The DOE-STD-3013-2000 credits formation of a hyperstoichiometric $\mathrm{PuO}_{2+\mathrm{x}}$ as the probable mechanism for $\mathrm{O}_{2}$ depletion. ${ }^{8}$ In gas generation tests at LANL on plutonium-bearing oxides, the major gas species present following long term storage were $\mathrm{N}_{2}, \mathrm{H}_{2}$, and $\mathrm{CO}_{2} \cdot{ }^{10}$ Formation of $\mathrm{CO}$ or $\mathrm{CO}_{2}$ is one plausible explanation for incomplete mass balance in these tests. Reaction with $\mathrm{N}_{2}$ is less likely based on the more or less constant $\mathrm{N}_{2}$ content of the headspace gas.

The measurement of headspace gas compositions associated with packaging, transportation, and storage of radioactive materials consistently demonstrates $\mathrm{O}_{2}$ depletion from air, except at high moisture contents. The moisture content required to achieve $\mathrm{O}_{2}$ generation has been studied for $\mathrm{PuO}_{2}$ and found to vary with SSA and dose rate. ${ }^{14}$ Neptunium dioxide processed per the HB-Line flowsheet contains significantly lower moisture levels than those where $\mathrm{O}_{2}$ generation has been observed for $\mathrm{PuO}_{2}$. Oxygen depletion has also been observed when studying the gas generation of transuranic (TRU) radioactive wastes. ${ }^{30}$ 


\section{Inerting the HB-Line $\mathrm{NpO}_{2}$}

Under conditions where the $\mathrm{H}_{2}$ gas is produced in a sufficient quantity to generate a flammable gas composition, the air may be replaced with an inert gas $\left(\mathrm{N}_{2}, \mathrm{Ar}, \mathrm{He}\right)^{31}$ to prevent combustion. This inerting step may only be credited for packages that are demonstrated to be leak tight and for which the contents do not generate $\mathrm{O}_{2}$ so that the $\mathrm{O}_{2}$ concentration remains at less than 5 vol $\%$.

Based on these elevated temperature $\mathrm{H}_{2}$ generation rate measurements, inerting $\mathrm{NpO}_{2}$ product packaged for shipment is necessary to avoid the potential for exceeding the lower flammable limit for $\mathrm{H}_{2}$ in air during a one-year shipping window. ${ }^{32}$ Prior $\mathrm{H}_{2}$ generation rate measurements for the HB-Line $\mathrm{NpO}_{2}$ product showed that inerting has the added benefit of significantly reducing the $\mathrm{H}_{2}$ generation rate. This decrease in rate is attributed to a reduction in moisture content associated with multiples cycles of reduced pressure and backfilling with a dry, inert gas. A similar reduction in the observed hydrogen generation rate should be anticipated for the HB-Line $\mathrm{NpO}_{2}$ product, as adsorbed moisture is removed by the inerting process. The moisture reduction associated with inerting the $\mathrm{NpO}_{2}$ content may be sufficient to drop the $\mathrm{H}_{2}$ generation below the threshold required for a one-year shipping window.

\section{Shipping in the 9975 Package}

The technical basis for shipping $\mathrm{PuO}_{2}$-bearing materials processed according to the DOESTD-3013-2000 was developed and approved as part of an earlier Safety Analysis Report - Packages 9972-9975 (SARP) revision. This earlier SARP demonstrated that inerting the payload is sufficient to protect the package integrity even with very high $\mathrm{H}_{2}$ pressures corresponding to approximately 1.4 moles of $\mathrm{H}_{2}$ gas inside the package. The maximum $\mathrm{H}_{2}$ content for proposed HB-Line $\mathrm{NpO}_{2}$ product should be less than one-half this amount, based on characterization of the laboratory-scale $\mathrm{NpO}_{2}$ product. Ambient temperature gas generation tests with $\mathrm{PuO}_{2}$ produced in a manner similar to the $\mathrm{NpO}_{2}$ and calcined to 950 ${ }^{\circ} \mathrm{C}$ indicated $\mathrm{H}_{2}$ generation rates between $3 \times 10^{-6}$ and $11 \times 10^{-6} \mathrm{~mol} \mathrm{day}{ }^{-1} \mathrm{~kg}^{-1}$. The maximum $\mathrm{H}_{2}$ generation rate observed for HB-Line $\mathrm{NpO}_{2}$ is $0.8 \times 10^{-6}$ mol day $\mathrm{kg}^{-1}$. However, the $9975 \mathrm{SARP}$ authorizes shipment of $\mathrm{PuO}_{2}$ with greater moisture content and impurity levels than evaluated in either of these $\mathrm{H}_{2}$ generation rate measurements.

Under the Materials Identification and Storage (MIS) program at LANL, the headspace gases from single samples of a representative material are packaged in a small test vessel to evaluate the performance of plutonium-bearing residues packaged per the DOE-STD3013-2000. The headspace gas of these containers will be measured periodically as part of a MIS shelf-life storage program. The results of this program and previous LANL studies on "pure" $\mathrm{PuO}_{2}$ have been used to establish the technical basis for shipping DOESTD-3013-2000 contents. This technical basis includes observations that $\mathrm{O}_{2}$ is depleted from air and is not liberated into the headspace gas of inerted containers. ${ }^{8,10}$ SRTC efforts to characterize the HB-Line $\mathrm{NpO}_{2}$ product and measure gas under a variety of experimental conditions are believed far more extensive than provided for most of the broad range of plutonium-bearing oxides shipped in the 9975 package. Because the $\mathrm{NpO}_{2}$ 
studied by SRTC has many characteristics that are similar to "pure" $\mathrm{PuO}_{2}$ addressed under the DOE-STD-3013-2000, the gas generation phenomena observed for transportation of $\mathrm{NpO}_{2}$ produced by HB-Line should be bounded by prior safety analysis for the transportation of the "impure" $\mathrm{PuO}_{2}$ included in the DOE-STD-3013 contents.

The $\mathrm{NpO}_{2}$ produced and tested by SRTC to represent the HB-Line product has a SSA similar to pure $\mathrm{PuO}_{2}$ calcined at $950{ }^{\circ} \mathrm{C}$. The moisture content associated with the HBLine $\mathrm{NpO}_{2}$ product is less than $0.2 \mathrm{wt} \%$, even for material calcined at $600{ }^{\circ} \mathrm{C}$, while the DOE-STD-3013-2000 allows moisture contents of up to $0.5 \mathrm{wt} \%$ on plutonium-bearing oxides. ${ }^{8}$ Based on a $6.8-\mathrm{kg} \mathrm{NpO}$ payload, the maximum water content will be less than $14 \mathrm{~g}$ in the 9975 . The $\mathrm{PuO}_{2}$ payload in the 9975 is limited to $0.5 \%$ of a $5.0-\mathrm{kg}$ payload, which allows up to $25 \mathrm{~g}$ of water to be shipped. Decreasing water from $25 \mathrm{~g}$ to $14 \mathrm{~g}$ will reduce the potential $\mathrm{H}_{2}$ pressure by approximately $45 \%$. The wattage of the $\mathrm{NpO}_{2}$ proposed for shipping in the 9975 (1.8 Watts) is less than $10 \%$ of the authorized wattage of $\mathrm{PuO}_{2}$ (19 Watts). In addition, the HB-Line $\mathrm{NpO}_{2}$ product contains far fewer impurities than are accepted in the DOE-STD-3013-2000 contents and shipped in the 9975 without the benefit of extensive gas generation testing. The impact of impurities on gas generation have been evaluated for the HB-Line product by using $\mathrm{NpO}_{2}$ samples generated using the HB-Line flowsheet from the same feed materials that will be used by HB-Line.

\section{Follow-up Experiments}

The $\mathrm{H}_{2}$ generation rate measurements provided by SRTC reflect average rates based on the experiment duration. Consequently, the anticipated decrease in $\mathrm{H}_{2}$ generation rate could be measured by analyzing additional headspace gas samples after another interval at elevated temperature. Additional tests to measure gas generation at elevated temperature with an inert Ar backfill may be useful to validate the decrease in $\mathrm{H}_{2}$ generation rate anticipated for an inerted package.

The headspace gas composition following about 30 days at elevated temperature contained approximately 75 to $80 \% \mathrm{~N}_{2}$ and less than $1 \% \mathrm{H}_{2}$. This result indicates that the $\mathrm{N}_{2}$ content of the headspace gas is relatively unchanged during the elevated temperature testing. The micro-GC used in this analysis showed that the $\mathrm{O}_{2}$ was largely depleted. This analysis was not set up to measure other gaseous species. About $20 \%$ of the headspace gas remained unmeasured in the elevated temperature tests compared to between 5 and $10 \%$ unmeasured gas in the ambient temperature tests. Additional efforts may be warranted to identify the unmeasured constituent(s) in the $\mathrm{NpO}_{2}$ headspace gas samples. 


\section{Conclusions}

The $\mathrm{H}_{2}$ gas generation rates for $\mathrm{NpO}_{2}$ samples produced on a laboratory scale using the HB-Line Phase II flowsheet and exposed to $75 \%$ RH have been measured at elevated temperature. The maximum rate measured under the reported test conditions exceeds the calculated limit for a one-year shipping window requested by HB-Line.

Test results on the laboratory-scale $\mathrm{NpO}_{2}$ samples show that the $\mathrm{O}_{2}$ concentration found in air decreases with time at both ambient and elevated temperature. The $\mathrm{O}_{2}$ depletion observed in these tests ensures an inert headspace gas (i.e., $<5 \% \mathrm{O}_{2}$ ) can be maintained for the HB-Line Phase II $\mathrm{NpO}_{2}$ product in a 9975 package. In addition, the process of inerting the $\mathrm{NpO}_{2}$ content should significantly reduce the $\mathrm{H}_{2}$ generation rate observed at elevated temperature, in much the same manner as observed in ambient temperature tests.

\section{References}

\footnotetext{
${ }^{1}$ WSRC-TR-2003-00389, “Gas Generation Testing of Neptunium Oxide Generated Using the HB-Line Phase II Flowsheet," R. R. Livingston and J. M. Duffey, Westinghouse Savannah River Company, Aiken, SC, August 2003.

${ }^{2}$ WSRC-TR-2003-00392, "Lab Scale Production of $\mathrm{NpO}_{2}$," M. G. Bronikowski, J. M. Duffey, and R. R. Livingston, Westinghouse Savannah River Company, Aiken, SC, August 2003.

${ }^{3}$ WSRC-TR-2003-00388, "Characterization of Neptunium Oxide Generated Using the HB-Line Phase II Flowsheet," J. M. Duffey and R. R. Livingston, Westinghouse Savannah River Company, Aiken, SC, August 2003.

${ }^{4}$ M-CLC-H-02495, "Thermal Analysis of the 9975 Package Containing Neptunium Oxide as a Payload for NCT and Accident Conditions," N. K. Gupta, Westinghouse Savannah River Company, Aiken, SC, October 2003.

5 AERE-M 1644, “ Gas Evolution from Solid Plutonium-Bearing Residues During Storage,” D. J. Hodkin, R. S. Pitman, P. G. Mardon, Atomic Energy Research Establishment, United Kingdom, 1965.

${ }^{6}$ RFP-502, "Measurements Involved in Shipping Plutonium Oxide,” J.T.Byrne, C.E. Caldwell, R.L. Delnay, J.D. Moseley, F.L.Oetting, The DOW Chemical Company Rocky Flats Division, 1965.

7 J.L.Stakebake, "The Storage Behavior of Plutonium Metal, Alloys, and Oxide," Journal of Nuclear Materials, Vol 38, pp 241-259, 1971.

${ }^{8}$ DOE-STD-3013-2000, "Stabilization, Packaging, and Storage of Plutonium-Bearing Materials," U. S. Department of Energy, Washington, D. C., September 2000.

9 DOE-STD-3028-2000, “Criteria for Packaging and Storing Uranium-233-Bearing Materials," U. S. Department of Energy, Washington, D. C., July 2000.

${ }^{10}$ LA-13781-MS, "Gas Generation from Actinide Oxide Materials," George Bailey, Elizabeth Bluhm, John Lyman, Richard Mason, Mark Paffett, Gary Polansky, G.D. Roberson, Martin Sherman, Kirk Veirs, Laura Worl, Los Alamos National Laboratory, Los Alamos, NM, 2000.

${ }^{11}$ ORNL/TM-2001/59, "Water Sorption and Gamma Radiolysis Studies for Uranium Oxides,” A.S. Icenhour, L.M. Toth, H. Luo, Oak Ridge National Laboratory, Oak Ridge, TN, 2002.

${ }^{12}$ N.G. Petrik, A.B. Alexandrov, A.I. Vall, "Interfacial Energy Transfer during Gamma Radiolysis of Water on the Surface of ZrO2 and Some Other Oxides," Journal of Physical Chemistry B, Vol. 105, pp 5935-5944, 2001.

${ }^{13}$ Mikio Nakashima, Yasuyuki Aratono, "Radiolytic Hydrogen Gas Formation from Water Adsorbed on Type A Zeolites," Radiation Physical Chemistry, Vol. 41, pp. 461-465, 1993.

14 J. M. Duffey and R. R. Livingston, "Gas Generation Testing of Plutonium Dioxide," paper presented at the Fifth Topical Meeting on Spent Nuclear Fuel and Fissile Materials Management, September 17-20, 2002, Charleston, SC.
} 
${ }^{15}$ WSRC-TR-99-00223, "Gas Generation Test Support for Transportation and Storage of Plutonium Residue Materials," Ronald R. Livingston, Westinghouse Savannah River Company, Aiken, SC, 1999.

${ }^{16}$ WSRC-TR-2001-00420, "Effects of Plutonium Dioxide Moisture Content and Calcination Temperature on the Headspace Gas Composition of Sealed Containers," Ronald R. Livingston, Jonathan M. Duffey, Westinghouse Savannah River Company, Aiken, SC, 2001.

${ }^{17}$ LA-UR-02-0584, "Analysis of Gas Constituents from Sealed Containers of Plutonium Oxide Materials," D. Kirk Veirs, Thomas H. Allen, John M. Berg, David D. Harradine, Dennis D. Padilla, Laura A. Worl, Los Alamos National Laboratory, Los Alamos, NM, 2002.

${ }^{18}$ A. O. Allen, C. J. Hochanadel, J. A. Ghormley, T.W. Davis, "Decomposition of Water and Aqueous Solutions under Mixed Fast Neutron and Gamma Radiation," Journal of Physical Chemistry, Vol. 56, pp. 575-586, 1952.

${ }^{19}$ C. J. Hochanadel, "Effects of Cobalt $\gamma$-Radiation on Water and Aqueous Solutions," Journal of Physical Chemistry, Vol 56, pp. 587-594, 1952.

${ }^{20}$ M. V. Vladimirova and I. A. Kulikov, "Formation of $\mathrm{H}_{2}$ and $\mathrm{O}_{2}$ in Radiolysis of Water Sorbed on $\mathrm{PuO}_{2}$, Radiochemistry, Vol. 44, pp. 86-90, 2002.

${ }^{21}$ M. V. Vladimirova , "A Mathematical Model of Radiolysis of Water Sorbed on $\mathrm{PuO}_{2}$, Radiochemistry, Vol. 44, pp. 455-460, 2002.

${ }^{22}$ Oil-in-Solvent Analysis, Savannah River Technology, Instrumentation and Examination Systems Section, Procedure L9.4-8309, Westinghouse Savannah River Company, Aiken, SC, 2003.

${ }^{23}$ ASTM E 104-85, Standard Practice for Maintaining Constant Relative Humidity by Means of Aqueous Solutions, American Society for Testing and Materials, 1996.

${ }^{24}$ WSRC-TR-2003-00354, "Micro Gas Chromatographic Analysis to Support Gas Generation Testing," A. E. Visser, R. R. Livingston, Westinghouse Savannah River Company, Aiken, SC, 2003.

${ }^{25}$ K. Viers, Los Alamos National Laboratory, Los Alamos, NM. Personal communication, August 2003.

${ }^{26}$ R. R. Livingston, J. M. Duffey, Westinghouse Savannah River Company, Aiken, SC. Unpublished data, July 2001.

${ }^{27}$ K. Ishigure, Y. Katsumura, G. R. Sunaryo, and D. Hiroishi, "Radiolysis of High Temperature Water," Radiat. Phys. Chem., (1995) Vol. 46, No. 4-6, pp. 557-560.

${ }^{28}$ RPP-5926, Rev. 0, "Steady-State Flammable Gas Release Rate Calculation and Lower Flammability Level Evaluation for Hanford Tank Waste,” T. A. Hu, S. A. Barker, J. D. Bingham, and M. A. Kufahl, April 2000.

${ }^{29}$ M. Tullmin; P. R. Roberge. Atmospheric Corrosion. In Uhlig's Corrosion Handbook, $2^{\text {nd }}$ Edition, R. W. Revie, Ed.; John Wiley and Sons: New York, 2000; pp 311-312.

${ }^{30}$ S. T. Kosiewicz, "Gas Generation from Organic Transuranic Wastes. I. Alpha Radiolysis at Atmospheric Pressure," Nuclear Technology, (1980) Vol. 54, p. 92-99.

${ }^{31}$ M. G. Zabetakis, "Flammability Characteristics of Combustible Gases and Vapors," Bulletin 627, U. S. Bureau of Mines, 1965.

${ }^{32}$ SRT-EMS-2003-00015, "Time to $\mathrm{H}_{2}$ Flammability Limit in 9975 with $\mathrm{NpO}_{2}$," M. A. Shadday, Westinghouse Savannah River Company, Aiken, SC, September 2003. 